\title{
SOCIAL SECURITY SURVIVORS' BENEFITS IN SOUTH AFRICA: TOWARDS LEGISLATIVE REFORM CONCERNING POSTHUMOUSLY CONCEIVED CHILDREN*
}

\author{
Rethabile Seema \\ LLB LLM \\ Assistant Lecturer, University of Johannesburg
}

SUMMARY

This purpose of this submission is to address the uncertainty regarding the legal status of posthumously conceived children and their entitlement to social security law survivors' benefits. In the quest to achieve this aim, focus will be directed not only to the current South African legislative framework, but specifically also to the United States of America's social-security survivors' benefits legislative and judicial framework for comparative reasons.

\section{$1 \quad$ INTRODUCTION}

The character of human life is one that is continuously surrounded by changes and advancements (for better or for worse), and we can apply the very same approach to medical science. Traditionally, human beings had the act of sexual intercourse as the only option for human reproduction. ${ }^{1}$ Today, assisted-reproductive technology offers human beings numerous options such as artificial insemination, ${ }^{2}$ in vitro fertilization, ${ }^{3}$ surrogacy ${ }^{4}$ and

* This article is based on an LLM dissertation in Social Security-Law submitted to the Faculty of Law, University of Johannesburg, Seema Social Security Survivors' Benefits in South Africa: Towards the Legislative Reform Concerning Posthumously Conceived Children (University of Johannesburg 2016).

1 Naguit "The Inadequacies of Missouri Intestacy Law: Addressing the Rights of Posthumously Conceived Children" 200974 Missouri LR 888.

2 Droghazi "Gillett-Netting $v$ Barnhart and unanswered questions about Social Security Benefits for Posthumously Conceived Children" 200583 Washington University Law Quarterly (WASHULQ) 1601 defines artificial insemination as "introducing sperm into the woman's vagina, cervical canal, or uterus".

3 Droghazi 200583 Washington University Law Quarterly (WASHULQ) 1601 defines in vitro fertilization as "removing ova, then adding sperm, and finally implanting any resulting preembryo(s) from the union of the sperm and the ova into the woman's womb".

4 Droghazi 200583 Washington University Law Quarterly (WASHULQ) 1601 defines (gestational) "surrogacy" as "the sperm and egg providers enter into an agreement with a woman to gestate and give birth to the child and then release the child to them". 
cryopreservation $^{5}$ to aid in procreation. As remarkable as these developments in medical science have been in giving prospective parents a "second chance", the developments have also created an unforeseen, special class of children that are conceived, and subsequently born, after one or both genetic parents have died. As early as 1866, a scientist, studying the physiology of sperm cells, speculated that someday "a man dying on the battlefield may beget a legal heir with his semen frozen and stored at home". ${ }^{6}$ Fast forward to today, the technology making it possible for that dying man to beget a biological heir is an accepted and celebrated part of the current medical landscape. ${ }^{7}$ The medical phenomenon that posthumously conceived children are a reality is here to stay, and as such, a medical reality with which the South African social security survivors' benefits legal system needs to become acquainted. It is true that when $\mathrm{O}^{\text {' }}$ Brien wrote that "As much as the law seeks to provide certainties, human evolution illustrates the continuity of uncertainty". ${ }^{8}$

The current problem facing the South African social-security legislative framework that posthumously-conceived children's eligibility to survivors' benefits, as a phenomenon caused by human evolution, is indeed illustrating the continuity of uncertainty is further perpetuated by the law not seeking to provide any certainty or clarity. The only logical solution for this problem would be for South Africa's policy-makers to always be cognizant of, and maintain momentum with, the ever-developing nature of modern reproductive technologies, so as to legislatively align themselves with these evolutions and ensure the adequate regulation of all parties involved.

\section{CURRENT LEGISLATIVE FRAMEWORK}

The provisions for the current South African social security survivor's benefits are found in several statutes. Each statute has its own requirements to be met. The different requirements found in the various statutes have created inconsistencies. Thus, there are no uniform standards of eligibility for survivors' benefits in South Africa. ${ }^{9}$

By way of an example, the definition of "children" in the various statutes collectively covers the majority of children, ${ }^{10}$ including posthumous children. ${ }^{11}$ However, posthumously-conceived children are not specifically mentioned in these statutes. As previously stated in above, the legislature

5 Droghazi 200583 Washington University Law Quarterly (WASHULQ) 1597 defines "cryopreservation" as "the freezing of sperm for later use in assisted reproduction".

6 Candidate "Late Fathers' Later Children: Re-conceiving the Limits of Survivor's Benefits in Response to Death-defying Reproductive Technology" 201415 Vanderbilt Journal of Entertainment and Technology Law 1015 cited Anger "Cryopreservation of Sperm: Indications, Methods and Results" 2003104 Urology 1079.

7 Sparrow "Orphaned at Conception: The Uncanny Offspring of Embryos" 2012 Bioethics 173.

8 O'Brien "The Moment of Posthumous Conception: A Model Act" $200925 \mathrm{~J}$. Contemp. Health L. \& Pol'y 332.

9 See Olivier "Death and Survivors' Benefits" in Olivier, Smit and Kalula (eds) Social Security: A Legal Analysis (2003) 302.

10 Namely: legitimate, illegitimate, adopted, foster, extra-marital and stepchildren.

11 A posthumous child is a child that is born after the death of a parent. 
needs to keep up with developments in the medical field and regulate their conditions of eligibility in the absence of a precedent.

\section{The Constitution of the Republic of South Africa 1996}

A fitting place to start this review is with the Constitution ${ }^{12}$ as it is the supreme law of the country. ${ }^{13}$ Any law or conduct that is not in accordance with the Constitution, either for the procedural or substantive reasons, will therefore not have the force of law. ${ }^{14}$ So far the very fact that the South African social security legal system, though well developed, is riddled by inconsistencies, lends the Constitution, to a great extent, to serve as a legislative foundation of the social-security system and, most importantly, as an adhesive that keeps the entire system together. ${ }^{15}$ The reasons behind these observations are discussed below.

\section{Constitutional supremacy}

Constitutional supremacy is one of the principles of law found under constitutionalism, ${ }^{16}$ which was introduced by the final Constitution. This principle states that the rules and principles of the Constitution are binding on all branches of the State, and have priority over any other rules made by the Government, the legislatures or the Courts. ${ }^{17}$ Constitutional supremacy clearly anticipates that the Constitution and its entrenched laws will at all times reign supreme and have priority over any law, principle or conduct contrary to it. This principle plays a fundamental role in this research because it serves as the driving force and the justification for which the legislature needs to amend the pertinent social security laws, and include posthumously conceived children as eligible dependants for survivors' benefits and prevents any further infringement of such children's constitutional rights. Furthermore, regardless of the fact that this class of children were possibly not foreseen as a reality, the Constitution and the constitutional Bill of Rights protect and provide for every type of child, thus ultimately providing posthumously-conceived children with the very same.

\section{The right to equality}

Section 9(1) of the Constitution provides "that everyone is equal before the law and has the right to equal protection and benefit of the law." One of the

Constitution of the Republic of South Africa 1996 (hereinafter "the Constitution").

$\mathrm{S} 2$ of the Constitution.

14 Executive Council Western Cape Legislature v President of the Republic South Africa 1995 (4) SA 877(CC).

152013 International Social Security Association Social: Security Coverage Extension in the BRICS A Comparative Study on the Extension of Coverage in Brazil, The Russian Federation, India, China, South Africa (ISSA) 138.

16 Currie and De Waal The Bill of Rights Handbook (2005) 8 defines constitutionalism as the idea that Government should derive its power from a written Constitution and that its power should be limited to powers set out in the Constitution.

17 Currie and De Waal The Bill of Rights Handbook 8, 9. 
admirable features of the Constitution is its delegation to the State regarding its aim to achieving a society based on equality, dignity and freedom. ${ }^{18}$ This assertion is evident from the wording of section 7(1) of the Constitution providing that "this Bill of Rights is a cornerstone of democracy in South Africa. It enshrines the rights of all people in our country and affirms the democratic values of human dignity, equality and freedom".

Despite equality being described as a "treacherously simple concept", ${ }^{19}$ it is, at its most basic and abstract, the formal idea that people who are similarly situated in relevant ways should be treated similarly. ${ }^{20}$ Equality is a foundational value that informs constitutional interpretation, as well as a fundamental right. ${ }^{21}$ The Constitution's aim in achieving a society, based on equality specifically can be taken seriously, as it expressly declares that everyone is equal before the law and has the right to equal protection before the law; ${ }^{22}$ as well as that equality includes the full and equal enjoyment of rights and freedoms. ${ }^{23}$ Furthermore, with the right to equality finding itself as the first right found in the Bill of Rights, ${ }^{24}$ the Constitution declares that national legislation must be enacted to prevent or prohibit unfair discrimination. ${ }^{25}$ According to Nyenti, the right to equality can form the basis for demands that rights are to be afforded to a person or category of persons. ${ }^{26}$ To this end, special measures may be taken to ensure the protection or advancement of people who have been disadvantaged by discrimination in the past. ${ }^{27}$

Thus it goes without saying that this study is of the view that posthumously-conceived children, like any other children, are worthy of the respect and protection of the law. ${ }^{28}$ Posthumously-conceived children, like any other children, are indeed similarly situated persons and thus, under the equality clause, are to be afforded similar treatment. Furthermore, this class of children as a category of vulnerable persons, is empowered by section 9 as a whole, to use the right to equality as the basis for demands for rights afforded to other similarly situated children. Ironically, the laws of exclusion and non-regulation of this class of children for survivor benefits, whilst including others, could be viewed as a direct violation of the Constitution's

$18 S$ 7(1) of the Constitution provides that "this Bill of Rights is a cornerstone of democracy in South Africa. It enshrines the rights of all people in our country and affirms the democratic values of human dignity, equality and freedom".

19 Holtmaat "The Concept of Discrimination" 2004 Academy of European Law Conference Paper 2.

20 Currie and De Waal The Bill of Rights Handbook 210.

21 Nyenti Developing an Appropriate Adjudicative and Institutional Framework for Effective Social Security Provisioning in South Africa (Doctoral Thesis, University of South Africa 2012) 38.

$22 \mathrm{~S} 9(1)$ of the Constitution.

$23 \mathrm{~S} 9(2)$ of the Constitution.

24 Currie and De Waal The Bill of Rights Handbook 210.

25 Ibid.

26 According to Nyenti Developing an Appropriate Adjudicative and Institutional Framework for Effective Social Security Provisioning in South Africa 39, "the social and economic status of social security applicants/beneficiaries has also been elevated to a ground in section 9(3), in terms of which a person may not be unfairly discriminated against".

27 Such as posthumously-conceived children.

28 See fn 23 above. 
instruction to the State to achieve a society based on equality, dignity and freedom.

\section{Formal and substantive equality}

The concept of "equality" in terms of our Constitution is divided into either formal or substantive equality. "Formal equality" on the one hand views everyone as equal bearers of rights ${ }^{29}$ and treats all individuals in the same way, despite there being any differences between such individuals. The idea of formal equality can be traced back to Aristotle's dictum that equality meant "things that are alike should be treated alike". ${ }^{30}$ Formal equality promotes individual justice as the basis for a moral claim to virtue and is reliant upon the proposition that fairness (the moral virtue) requires consistent or equal treatment. ${ }^{31}$ Thus in terms of this concept of equality, which means sameness of treatment, ${ }^{32}$ posthumously-conceived children should not be treated differently from other children. Expressly deeming this class of children eligible for social security survivor benefits, in a formal sense, ensures that necessary, effective legislation will be put in place to protect their rights and interests.

"Substantive equality", on the other hand, is not a concept trying to achieve sameness of treatment; it is a concept focusing rather on equality of outcomes. ${ }^{33}$ In its quest to uphold its constitutional commitment, substantive equality requires the law, when determining the attainment of equality, ${ }^{34}$ to safeguard equality of outcome whilst taking into account the actual social and economic disparities between groups or people. ${ }^{35}$ The inclusion of section 9(2) in the equality clause illustrates the Constitution embracing and implementing a substantive concept of equality. ${ }^{36}$ Thus unlike formal equality, substantive equality actually addresses the Constitution's commitment to carefully and thoroughly understand the impact that a history

29 Currie and De Waal The Bill of Rights Handbook 213.

30 Aristotle Ethica Nicomachea 112-117, 1131a-1131b; Arckrill and Urmson (eds) W Ross Translation Oxford University Press 1980 http://www.equalrightstrust.Org/ertdocumentbank /The\%20Ideas\%20of\%20and\%20Non-discrimination,\%20Formal\%20and\%20Substantive\% 20Equality.pdf (accessed 2014-11-10).

31 Wesson "Equality and Social Rights; An Exploration in light of the South African Constitution" 2007 Public Law 751.

32 Currie and De Waal The Bill of Rights Handbook 213.

33 Ibid, citing Loenen "The Equality Clause in the South African Constitution: Some remarks from a Comparative Perspective" 1997 SAJHR 405, 410. For eg, on a formal concept of equality, equality is achieved if all children are educated according to the same school curriculum. Substantive equality on the other hand would require equality of outcome. If children with disabilities (deaf, for eg,) undergo the same school programme as other children they may very well end up receiving an education that is inadequate for their special needs. To realize the equality of treatment of these children it may therefore be necessary to treat them differently to everyone else.

34 Currie and De Waal The Bill of Rights Handbook 213.

35 Ibid.

36 S 9(2) of the Constitution provides that "Equality includes the full and equal enjoyment of rights and freedoms. To promote the achievement of equality, legislative and other measures designed to protect and advance other persons, or categories, disadvantaged by unfair discrimination may be taken". 
of discriminatory action had on a category of individuals or group. ${ }^{37}$ The State has committed itself to substantive equality, which means that persons suffering from any disadvantage are entitled to extra protection. ${ }^{38}$ This means that the State has a constitutional duty to ensure that the most vulnerable members of society are prioritized. As regards children's rights, this means that vulnerable groups of children (for example, children with disabilities, refugees, and posthumously-conceived children) are entitled to special protection. ${ }^{39}$

Section 9 would demand that the legislature include posthumouslyconceived children into the legal framework and regulate the conditions of their eligibility for survivor benefits. A substantial approach to equality permits, recognizes and requires positive measures of support to be extended for the needs of particular disadvantaged individuals and groups, to address inequality and remedy disadvantage by enabling them to enjoy full and equal access to their constitutional rights. ${ }^{40}$ The need for the adoption of substantive equality is further necessitated by the Constitution's focus on particularly vulnerable and desperate persons. The State's constitutional obligations require that the State protects particularly vulnerable and desperate persons and groups. The Constitutional Court has stated that the State has to make provision for the most vulnerable and desperate in society. ${ }^{41}$ Thus, ironically as much as the concepts of formal equality and substantive equality are at polarity, both concepts support the view that posthumously-conceived children are worthy of equal treatment and protection. Either as being equal bearers of rights and freedoms, ${ }^{42}$ as is every child, or as being a special class in need of a distinct type of protection, so as to achieve an equality outcome. ${ }^{43}$ Both these concepts, when applied to the objective of section 9, successfully advance the Constitution's aim to achieve a society based on equality, dignity and freedom.

\section{Unfair discrimination}

Discrimination is action that denies social participation or human rights to categories of people, based on prejudice. ${ }^{44}$ This includes treatment of an individual or group, based on their actual or perceived membership of a certain group or social category "in a way that is worse than the way people

\footnotetext{
Nyenti 2012 University of South Africa 28.

Ibid.

Ibid.

40 As O'Regan J, observed in Brink v Kitshoff NO 1996 (4) SA 197 (CC), 1996 BCLR 752 (CC), the purpose of the constitutional-equality clause is to prohibit patterns of group-based disadvantage and harm, and to permit positive steps to redress the effects of such discrimination.

41 Nyenti 2012 University of South Africa 41; Government of the Republic of South Africa v Grootboom 2000 (11) BCLR 1169 (CC); 2001 (1) SA 46 (CC).

42 In terms of formal equality everyone is an equal bearer of rights.

43 In terms of substantive equality individual needs are considered in order to achieve equality of outcome.

44 Oxford dictionary (11 December 2004) http://en.oxforddictionaries.com/definition/ discrimination (accessed 2014-11-11).
} 
are usually treated". ${ }^{45}$ However, the equality clause does not prohibit discrimination but rather unfair discrimination. The implication of this terminology is that not all discrimination is unfair. ${ }^{46}$ Fairness is a moral concept that distinguishes legitimate from illegitimate discrimination. ${ }^{47}$ What then constitutes unfair discrimination? The impact of the discrimination on its victims will be the deciding factor. ${ }^{48}$ Unfair discrimination "principally means treating people differently in a way which impairs their fundamental dignity as human beings, who are inherently equal in equal." 49 Legally unfair discrimination manifests when law or conduct, for no good reason, treats some people as inferior or incapable or less deserving of respect than others. It also occurs when law or conduct perpetuates or does nothing to remedy existing disadvantage and marginalization. ${ }^{50}$ Section 9(3), (4) and $(5)^{51}$ state that neither the State nor any individual may directly or indirectly unfairly discriminate against anyone on illegitimate grounds. Discrimination on illegitimate grounds is discrimination on the listed grounds, found in section 9(3) and on the analogous grounds. ${ }^{52}$

\section{The listed grounds}

Differentiation on the basis of one of the grounds listed in section 9(3) is presumed to be unfair discrimination until the contrary is proved. ${ }^{53}$ These grounds have the potential, when manipulated, to demean persons in their inherent humanity and dignity. ${ }^{54}$ A claim may be brought on "one or more" of the listed grounds. ${ }^{55}$ This is such due to there often being a complex relationship between these grounds. ${ }^{56}$ The existence of a complex

45 Cambridge dictionaries online (29 March 2013) http://dictionary.cambridge.org/dictionary/ english/discrimination (accessed 2014-11-11).

46 Currie and De Waal The Bill of Rights Handbook 223.

47 Currie and De Waal The Bill of Rights Handbook 223; Alberton "Equality" in Cheadle, Davis and Haysom (eds) South African Constitutional Law: The Bill of Rights (2002) 105.

48 Harksen v Lane NO 1998 (1) SA 300 (CC).

49 Prinsloo v Van der Linde 1997 (3) SA 1012 (CC). According to Currie and De Waal, the value of dignity is thus of central importance to understanding unfair discrimination. Unfair discrimination is differential treatment that is hurtful or demeaning.

50 Currie and De Waal The Bill of Rights Handbook 223.

$51 S 9(3)$ of the Constitution provides that the State may not unfairly discriminate directly or indirectly against anyone on one or more grounds, including race, gender, sex, pregnancy, marital status, ethnic or social origin, colour, sexual orientation, age, disability, religion, conscience, belief, culture, language and birth. S 9(4) states that no person may unfairly discriminate directly or indirectly against anyone on one or more grounds in terms of subsection 3. National legislation must be enacted to prevent or prohibit unfair discrimination. $S$ 9(5) of the Constitution provides that discrimination on one or more of the grounds listed in subsection (3) is unfair unless it is established that the discrimination is fair.

52 In Currie and De Waal The Bill of Rights Handbook 222-223 differentiation on a ground that is not on the list of presumptively illegitimate grounds of differentiation in $s 9(3)$ will be discrimination if the ground is analogous to the listed grounds.

53 Currie and De Waal The Bill of Rights Handbook 227.

54 Currie and De Waal The Bill of Rights Handbook 249, citing Harksen v Lane supra 49.

55 Currie and De Waal The Bill of Rights Handbook 227.

56 In Harksen $v$ Lane supra 49, the Constitutional Court held that in some cases these grounds relate to immutable biological attributes or characteristics, in some to the associational life of human beings, in some to the intellectual, expressive and religious dimensions of 
relationship between these groups in essence serves to illustrate how one act or omission can have far-reaching consequences. ${ }^{57} \mathrm{~A}$ detailed analysis of the relevant listed acts of unfair discrimination suffered by posthumouslyconceived children due to the lack of or non-existence of legal recognition deeming them eligible for social security survivors' benefits, is discussed below.

\section{Birth}

One could argue that the exclusion of posthumously-conceived children or the lack of express legislation deeming them eligible for social security benefits, whilst including all categories of children, is identical to the treatment that illegitimate children were handed by the law. ${ }^{58}$ Worldwide, "illegitimate" children, as they were referred to historically (and even now by some courts), suffered significant legal and societal discrimination. ${ }^{59}$ These children had no legal right to parental support, intestate succession, or Government benefits available to marital children. ${ }^{60}$ Another factual reason why posthumously-conceived children do mirror to illegitimate children, is due to the fact that they are conceived and born after a parent dies, thus legally implying that they are children whose biological parents were not married at the time the child was conceived. ${ }^{61}$ This treatment is indeed unconstitutional. In the Bhe $v$ Magistrate, Khayelitsha case, ${ }^{62}$ the Constitutional Court held that the prohibition of unfair discrimination on the ground of birth in section 9(3) of our Constitution should be interpreted to include a prohibition of differentiating between children on the basis of whether a child's biological parents were married, either at the time the child was conceived, or when the child was born. ${ }^{63}$ While "illegitimacy" is not specifically listed as a ground of unfair discrimination in section 9(3), it is covered by the listed ground of "birth". This means that any form of differentiation between the status of the children on grounds of the marital status of their parents at the time of their birth is presumed unfair. ${ }^{64}$ The unsatisfactory regulation of the situation of posthumously-conceived children appears to be in contravention of section 9(3), thus amounting to unfair discrimination on the grounds of birth. Posthumously-conceived children

humanity, and in some cases to a combination of one or more of these features. The temptation to force them into neatly self-contained categories should be resisted.

is case, it is an omission due to the lack of explicit legislation.

58 The term "illegitimate" is derived from the Latin illgitimus, meaning "not in accordance with the law." An illegitimate child is one conceived and born outside of regulatory sanctions of marriage Encyclopedia.com www.encyclopedia.com/topic/illegitimacy.aspx (accessed 201505-19)); Bainham "Is Legitimacy Legitimate?" 2009 Family Law 673 explains that for years, the Courts have used the term "illegitimate" or "the illegitimates" to refer to non-marital children. The use of the term itself, and its continuing usage today suggests that non-marital children are somehow different and inferior to marital children.

59 Maldonado "Illegitimate Harm: Law, Stigma, and Discrimination against Non-marital Children" 2013 Florida LR 346.

60 Maldonado 2013 Florida LR 347.

61 Owing to death of one spouse dissolving the marriage contract.

62 Bhe v Magistrate, Khayelitsha 2005 (1) BCLR 1 (CC).

63 Bhe $v$ Magistrate, Khayelitsha supra 46

64 Ibid. 
may not have been conceived the same way as the majority of children. Nonetheless, they are children and their exclusion cannot be justifiable. ${ }^{65}$ Furthermore, because these children do not choose the circumstances of their births, the State may be unwittingly unfairly discriminating against them by imposing disabilities on them despite their not being responsible for their own birth - this is both ineffectual and unjust. ${ }^{66}$

\section{Sex, procreation and pregnancy}

This particular ground seeks to demonstrate the far-reaching negative effects of the current unsatisfactory social security survivors' benefits regime. By the legislature inadequately regulating the conditions of eligibility for posthumously conceived children within the current legal framework, the legislature is indirectly unfairly discriminating against women on the grounds of sex and pregnancy. This is unfair discrimination on the grounds of pregnancy because women, who after the death of a spouse (still) wish to become parents and wish to utilize the services of modern reproductive technology, can be deterred from pursuing their aspirations of procreating due to the current negative implications of having a posthumously-conceived child. ${ }^{67}$ Furthermore, discrimination on the basis of pregnancy could also be viewed as discrimination on the grounds of sex, since only women can fall pregnant. ${ }^{68}$ The Constitution arguably provides woman with the affirmative right to procreate, as opposed to the right not to procreate, due to this right tying in with other fundamental rights. ${ }^{69}$ The legislature should work towards reforming posthumously-conceived children's legislative entitlements to survivors' benefits so as not to infringe upon the parents constitutionallyprotected rights to procreation, family relationships, parenting and marriage. ${ }^{70}$ Mainly due to the fact that one's right to procreate, conceive and essentially raise one's child(ren) is an essential right, basic to humankind fundamental to the very survival of a race, ${ }^{71}$ regardless if such a right is practised posthumously.

65 Kennedy "Social Security Survivor Benefits: Why Congress Must Create a Uniform Standard of Eligibility for Posthumously Conceived Children" 2013 Boston College LR 853.

66 Ibid.

67 In Harwood "Posthumous Reproduction" http://uncpressblog.com/2011/05/19guest-postkarey-harwood-on-posthumous-conception/ (accessed 2015-06-18), Karey discusses the far reaching negative implications of how inadequate legislation, plus ever-developing modern reproductive technologies, combined with a human being's "right to parenthood" have reached previously inconceivable levels as seen in Israel when the people who were asserting their "right to parenthood" and commissioning the creation of the posthumouslyconceived child were the grandparents. An Israeli couple, Mali and Dubi Ben-Yaakov, whose 27-year old son died single and childless, introduced a new dynamic to the posthumous conception saga when they sought to have their "right to grandparenthood" legally acknowledged.

68 Woolworths (Pty) Ltd v Whitehead 2000 (12) BCLR 1340 (LAC).

69 Nolan "Posthumous Conception: A Private or Public Matter?" 1997 Brigham Young University Journal of Public Law 14.

70 Nolan 1997 Brigham Young University Journal of Public Law 15.

71 Ibid. 


\section{Direct and indirect discrimination}

There are two forms of discrimination related to unfair discrimination, namely direct and indirect discrimination. These are both prohibited by the Constitution, thus ensuring that all forms of discrimination, whether listed or analogous, are accounted for. Direct discrimination is easily identifiable and involves overt differential treatment between similarly situated persons on the basis of arbitrary grounds. ${ }^{72}$ Indirect discrimination on the other hand, is not as easily recognizable, as it is a more subtle form of discrimination. It involves the application of policies and practices that are apparently neutral and do not explicitly distinguish between similarly situated persons, but that, in reality, have a disproportionate and negative effect on certain people and groups. ${ }^{73}$

In Waters $v$ Public Transport Corporation, ${ }^{74}$ the High Court summarized the distinction between direct and indirect discrimination as follows:

"Broadly speaking, direct discrimination occurs when one person is treated in a different manner (in a less favourable manner) from the manner in which another is or would be treated in comparable circumstances on the ground of some unacceptable consideration (such as sex or race). On the other hand, indirect discrimination occurs where one person appears to be treated just as another is or would be treated but the impact of such 'equal' treatment is that the former is in fact treated less favourably than the latter".

Hence, despite the current social-security legal framework seeming neutral in its treatment of all children, ${ }^{75}$ it could be viewed as indirectly discriminating against posthumously-conceived children. This is because the manner in which it is administered, which leads to these children being unfairly discriminated against.

\section{Human dignity}

Section 10 of the Constitution states that "everyone has inherent dignity and the right to have their dignity respected and protected". Section 1 states that the Republic of South Africa is a sovereign democratic State, founded on values of human dignity, the achievement of equality and the advancement of human rights and freedoms; while section 7(1) affirms, amongst others, ${ }^{76}$ the democratic value of human dignity. The right to have one's dignity

72 "Discrimination Definition" The Commission for Conciliation, Mediation and Arbitration www.ccma.org.za/UploadedMedia/InfoSheets DISCRIMINA-TION\%20-\%20JAN\%202002 \%281\%29.html (accessed 2014-10-07).

73 Ibid.

74 Waters v Public Transport Corporation (1991) HCA 49.

75 It could be viewed as being neutral because no social-security schemes expressly exclude or prohibit posthumously-conceived children from receiving benefits, which, if they had, would have amounted to direct discrimination. The problem or discrimination lies in the fact that none of these schemes explicitly provide for these children's access to survivors' benefit. The lack of clear and precise law for posthumously-conceived children on one hand, opposed to the inclusion of every other category of child on the other hand, could be seen as indirect discrimination.

76 Namely the democratic values of equality and freedom. 
respected and protected is thus one of the core constitutional rights. ${ }^{77}$ By including and recognizing the right to dignity, the Bill of Rights sought to "safeguard and promote" the value of human dignity. ${ }^{78}$

Though we can be certain of the paramount importance of human dignity in the Constitution, we can be less certain of the meaning of the concept. ${ }^{79}$ According to Chaskalson, its origins have been traced to Kantian moral philosophy, where human dignity is considered to be that which gives a person its intrinsic worth. ${ }^{80}$ According to this philosophical thought, dignity is "above all price and so admits of no equivalent". ${ }^{81}$ Despite it being a "difficult concept to capture in precise terms", ${ }^{82}$ the value of human dignity accordingly also provides the basis for the right to equality - inasmuch as every person possesses human dignity in equal measure everyone must be treated as equally worthy of respect. ${ }^{83}$ In $S \vee$ Makwanyane the Court in its pursuit of defining "human dignity", pointed out that the right to dignity is intricately linked with other human rights: "Recognizing a right to dignity is an acknowledgement of the intrinsic worth of human beings: human beings are entitled to be treated as worthy of respect and concern. This right therefore is the foundation of many of the other rights that are specifically entrenched in ... (the Bill of Rights)." 84

Like equality and freedom, human dignity is also both a foundational value and a fundamental right that will inform the entire social-security legislative framework. ${ }^{85}$ This is such due to this right being one of the core constitutional rights. ${ }^{86}$ Owing to the fact that the aim of social security is to allow a person to live with human dignity, ${ }^{87}$ it follows that the interpretation of the core value of human dignity will form the basis for the extent of justiciability of the right to social security. As all of the values contained in the Constitution need to be interpreted together, this is also an important

77 De Waal, Currie and Erasmus Bill of Rights Handbook (2001) 230, recognise the right to human dignity as a core constitutional right. S 10 does not, however, specifically grant a right to human dignity. Instead it recognizes everyone's inherent dignity and grants them the right to have such inherent dignity respected and protected.

78 Currie and De Waal The Bill of Rights Handbook 251.

79 According to fn 68 above, "as is typical of its treatment of important abstractions in the Constitution, the Constitutional Court has not ventured a comprehensive definition of human dignity".

80 Chaskalson "Human Dignity as a Foundational Value in our Constitutional Order" 2000 SAJHR 204.

81 Jones Kant's Principle of Personality (1971) 127.

82 National Coalition for Gay \& Lesbian Equality v Minister of Justice 1999 (1) SA 6 (CC) par 29.

83 In National Coalition for Gay and Lesbians Equality v Minister of Justice 1999 (1) SA 6 (CC), the Court held that "the rights of equality and dignity are closely related, as are the rights of dignity and privacy".

84 S v Makwanyane 1995 (3) SA 391 (CC).

85 Goolam Human Dignity - Our Supreme Constitutional Value (Unpublished paper delivered at the International Conference on Development in the Contemporary Constitutional State 2000) 4.

86 De Waal, Currie and Erasmus Bill of Rights Handbook 230.

87 Horsten The Social Security Rights of Children in South Africa (Thesis SA) 2003 23; Venter "Die Betekenis van die Bepalings van die Grondwet die Aanhef en Hoofstuk 1" 1998 Potchefstroomse Elektroniese Regstydskrif 27-29 http://www.puk.ac.za/ lawper/ tydskrif/ 1998v1.html (accessed 2002-07-26). 
step for constitutional values in the interpretation of socio-economic rights. ${ }^{88}$ Section 10 makes it clear that not only does everyone have a right to human dignity, but that human dignity is inherent in each human being. Human dignity is something everyone is born with, something that no man can take and will ever be allowed to take away from another. Posthumouslyconceived children are thus legally and constitutionally entitled to have their right to human dignity respected and protected. Thus, the envisaged meaningful legal recognition of this class of children would be in line with the accepted approach that the universal aim of social security is to allow a person to live in a manner consistent with his/her right to human dignity. ${ }^{89}$

\section{Marriage and family life}

The family is recognized as the most natural and fundamental unit of society and requires the full protection of the State. ${ }^{90}$ Therefore the right of all to marry and found a family is protected in human rights law, which upholds the positive right of all people to do such. It upholds the ideal of equal and consenting marriage and tries to guard against certain abuses which undermine these principles. What is of importance is that it is not prescriptive as to the types of families and marriages that are acceptable, recognizing tacitly that there are many different and diverse forms of families and marriages in the Republic. ${ }^{91}$ The right to marriage and a family life encompasses the right of an individual to belong to a family unit, the right of a couple to marry and live together, the right to bear children, the right of parents to raise their children and care for them, the right of children to grow up with their parents - and is therefore grounded in the constitutional rights to privacy, self-fulfilment, and dignity. ${ }^{92}$ Thus the ground of marital-status discrimination seeks to make suspect the imposition of burdens on married persons that it does not impose on those who are not married. ${ }^{93}$

Where some people may celebrate the creation that is posthumouslyconceived children, other persons may view this new class of children as a violation of what Mother Nature stands for. As such, the negative perceptions and social discrimination suffered by posthumously-conceived children will inevitably also be felt by the persons electing to utilize such modern reproductive technologies. An individual's right to belong to a family unit, an individual's wish to extend his or her family unit is something that

88 Horsten The Social Security Rights of Children in South Africa 24; According to Sachs "Reflection on Emerging Themes" 1999 ESRR 14, these rights are about dignity and having meaningful control over one's life.

89 Ben-Israel "Social Security in the Year of 2000: Potentialities and Problems" 2005 Comparative Labour Law Journal 139.

90 Article 16(3) of the Universal Declaration of Human Rights.

91 Naik "The Right to a Family" 2003 Human Rights Education Association www.hrea.org/index.php?base_id=158 (accessed 2014-10-28).

92 According to Merin "The Right to Family Life and Civil Marriage under International Law and its implementation in the State of Israel" 2005 Boston College International and Comparative $L R$ 86, "in an era in which 'human dignity' is a protected fundamental constitutional right, effect should be given to the aspiration of a person to fulfil his personal being, and for this reason, his desire to belong to a family unit that he considers himself part of should be respected".

93 Currie and De Waal The Bill of Rights Handbook 232; see fn 48 above. 
should not be taken lightly or ignored by the law. Unfortunately, it can be argued that the lack of clear legislation pertaining to the rights or legal status of posthumously-conceived children's survivor-benefits eligibility could accrue to legal and societal discrimination by the State on the grounds of marriage and family life, ${ }^{94}$ towards those individuals who wish to conceive through unconventional methods.

Another strong argument that would be in favour of the amendment of posthumously-conceived children's eligibility for survivor benefits, and consequently stop the infringement of one's right to marriage and family life, is if the legislature would be cognizant of the likelihood that, despite being conceived and born posthumously, children do not view their family structure as wronging them or their dignity in any way. ${ }^{95}$ Unlike adults, who often frame familial structures as right or wrong, good or bad, children are particularly adept at developing strategies to comprehend complex family relationships. ${ }^{96}$

It is for this reason that the Constitution not only affords posthumouslyconceived children rights, but it was held in Dawood ${ }^{97}$ that parents' right to dignity must be interpreted to afford protection to the institution of marriage and family life. Writing for the Court, O'Regan J, held that the Court indeed protected the rights of persons to freely marry and raise a family. ${ }^{98}$ Failure by the current legal framework to regulate the eligibility or ineligibility of posthumously-conceived children undermines an individual's desire to have and raise a family after the death of a spouse. The legislature further fails to foresee that it could be impairing the ability of an individual to achieve personal fulfilment in an aspect of life that is of central significance. ${ }^{99}$ Ultimately, this weak regulation causes a domino effect that not only violates the child's human dignity, but also his/her parent's human dignity caused by the infringement on their right to a family life.

\section{Children's rights}

Section 28 of the Constitution provides a range of constitutional rights that provides protection exclusively for children. These children's rights are additional to the protection afforded to them in the remainder of the Bill of Rights. This section relates directly to the social security rights of children ${ }^{100}$

94 Alsgaard "Recent Developments Decoupling Marriage and Procreation: A Feminist Argument for Same-sex Marriage" 2012 Berkeley Journal of Gender, Law and Justice 308 writes in his article that he is of the view that "if we think about marriage in the broader context, we will realize our concerns about marriage flow primarily from the fact that it usually involves children. On this view, we have a social justice in marriage not for its own sake, but because marriage traditionally is the institution in which procreation has occurred."

95 Sabatello "Posthumously Conceived Children: An International and Human Rights Perspective" 2014 Journal of Law and Health 60; Moyal and Shelly "Future Child's Rights in New Reproductive Technology: Thinking outside the Tube and Maintaining the Connections" 2010 Family Court Review 436.

96 Ibid; Mason and Tipper "Being Related: How Children Define and Create Kinship" 2008 Childhood 441.

97 Dawood v Minister of Home Affairs 2000 (3) 936 (CC).

98 Ibid.

99 O'Regan in Dawood v Minister of Home Affairs par 37.

100 Robinson Word and Action (1996) 9. 
and as such, its main objective being the protection of vulnerable children. Posthumously-conceived children find themselves in a very unfortunate situation, due to the manner in which they are treated by the social security legislative framework.

Each child is afforded socio-economic rights, inclusive of the right to social security, which are all entrenched by the Constitution. ${ }^{101}$ As such the Constitution places a duty on the State to ensure that each child is provided with these basic needs. By the current law not accommodating posthumously-conceived children access to their survivors' benefits leads to an infringement, as provided for by section 28 . The legislature needs to reform the current legislative framework pertaining to posthumouslyconceived children, because as Duncan puts it "the Constitution possess the status of the highest standards by which all acts and omissions are evaluated and also have the binding force of the law, their role as tools of change in favour of children cannot be underestimated". ${ }^{102}$

\section{The "best interest" standard}

In terms of section 28(2), a child's interests are of paramount importance in every matter concerning that child. The best interests of the child have been elevated to a standard ${ }^{103}$ and a right ${ }^{104}$ with the commencement of the Children's Act 38 of 2005.

As a standard and a right, the "best interest" yardstick is placed in the hands of the Courts in their capacity as the upper guardians when hearing every matter dealing with children. The "best interest" standard is also placed in the hands of the legislature, in that the standard must always be adhered to and promoted when enacting or reforming legislation dealing with children. The drafters of the Constitution have made children's rights a priority, and have stated that the best interest of the child is the overriding concern when it comes to any matter affecting him or her. ${ }^{105}$ Therefore, it is argued that until legislative reforms have been implemented to ensure the social security coverage of these children, it would appear that the legislature is not placing a child's best interest as being paramount, thus violating section 28 . As such, the State itself has a legitimate interest in defining posthumously-conceived children's eligibility, ${ }^{106}$ in order to avoid the (further) infringement of this yardstick.

\footnotetext{
101 Mpedi "Posthumously Conceived Children and their (in)eligibility for Survivors' Benefits: Implications for the South African Social Security System" 2012 Inaugural Address 10.

102 Duncan "Constitutional Reforms in Favour of Children" 2008 United Nations Children's Fund 2.

103 S 7 and 9 of the Children's Act 38 of 2005 (the Children's Act).

104 S 8 of the Children's Act.

105 Duncan 2008 United Nations Children's Fund 17.

106 Duncan 2008 United Nations Children's Fund.2.
} 


\section{Section 27 of the Constitution}

The Constitution ${ }^{107}$ introduced the concept of social security by including section 27.108 Section 27 extends the right to access of social security to everyone. This includes appropriate social assistance in a case where they are unable to support themselves and their dependants.

From this provision, it can be inferred that a posthumously-conceived child does indeed have a right to access to social security, both as an individual ("everyone"), and as the deceased's natural offspring ("dependant"). ${ }^{109}$ Fundamentally section 27(1)(c) indicates to one's constitutional right to access to social security, thus it also indicates to posthumously-conceived children's constitutionally-protected entitlement to survivors' benefits. It is therefore not fair that these children should continue being excluded and marginalized due to the absence of legislation expressly including them as eligible dependants for survivors' benefits. Moreover, posthumouslyconceived children should not be prejudiced because the underlying goal of the children's survivors' benefits is to replace the lost financial support of the deceased wage-earner in order to keep families together and give children the opportunity to grow up securely. ${ }^{110}$ Thus, it is important for the law to recognize that posthumously-conceived children deserve the same chance to become productive members of society as any child, and if supporting one group is good for the future economic stability, then supporting the other is too. ${ }^{111}$

107 See fn 12 above.

108 S 27(1) of the Constitution provides that everyone has the right to have access to -

(a) health-care services, including reproductive health care;

(b) sufficient food and water; and

(c) social security, including, if they are unable to support themselves and their dependants, appropriate social assistance.

109 An important matter to take note of is that the majority of social-security survivors' benefits legislation in South Africa distinguishes between two types of dependants, namely, legal (de iure) dependants and factual (de facto) dependants. Legal dependants are viewed as the spouse who was legally married to the deceased employee and the children of the deceased employee, thus, the deceased's immediate family. Factual dependants on the other hand were/are those who were/are dependant on deceased's salary but are said to be outside his immediate family circle. Two pieces of legislation that make reference between the two types of dependants are the Compensation for Occupational Injuries and Diseases Act 130 of 1993 and the Pension Fund Act 24 of 1956.

S 1 of COIDA states that a "dependant" includes the employees surviving spouse/partner, kids, and certain family members who were wholly and partially dependant on the employee at the time of his death. Thus both legal and factual dependency suffice.

S 1 of the Pension Fund Act defines "dependant" as follows: "a person in respect of whom the member is legally liable for maintenance, a person in respect of whom the member is not legally liable for maintenance". Thus also distinguishing and providing for both de iure and de facto dependants.

110 Kennedy 201354 Boston College LR 826.

111 Kennedy 201354 Boston College LR 853. 


\section{Social security in South Africa}

Neither South African nor international literature provides a clear definition of the concept "social security". ${ }^{112}$ Hence, "social security" is elastic and varies from one country to the other. ${ }^{113}$ Nevertheless, the most common definition follows the International Labour Organization's (ILO) approach, and defines "social security" on the basis of the so-called nine classical risks (namely, sickness, maternity, employment injury, unemployment, invalidity, old age, death, medical care and family) embodied in the Social Security (Minimum) Standards Convention 102 of 1952. Consequentially, social security is perceived as:

"the protection that society provides for its members, through a series of public measures, against the economic and social distress that otherwise will be covered by the stoppage or reduction of earnings resulting from sickness, maternity, employment injury, unemployment, invalidity, old age, death, provision of medical care and provision of subsidies for families with children." 114

The South African social-security system has to a large extent been constructed around social assistance and social insurance. ${ }^{115}$ It is for this reason that this research focuses mainly on these two strategies.

\section{Social insurance}

Social insurance is a "is a mandatory contract whereby for some consideration, usually but not necessarily for periodical payments called premiums, you secure to yourself some benefit, usually but not necessarily the payment of a sum of money, upon the happening of some event". ${ }^{116}$ Social insurance is normally aimed at poverty prevention and generally financed through contributions from covered employees, their employers and the Government. ${ }^{117}$ The scope of coverage of a social-insurance scheme, as a rule, extends to employees in designated categories and their dependants. ${ }^{118}$ Thus in order to benefit, there must exist a specific relationship between the contributor and the prospective beneficiary. ${ }^{119}$ From the above description, it is evident that the South African socialinsurance system is largely linked to formal employment. ${ }^{120}$

Children cannot contribute to social-insurance schemes themselves, due to the schemes being largely linked to formal employment, but they are

112 See Olivier in Olivier, Smit and Kalula (eds) Social Security: A Legal Analysis 23.

113 Olivier and Mpedi The Complementary Role of Formal and Informal Social Security in Extending Social Protection: A South African Perspective (2003) 1.

114 International Labour Organization 200029.

115 Mpedi Pertinent Social Security Issues in South Africa (2008) 7.

116 Prudential Insurance Co v Inland Revenue Commissioners (1904) 2 KB $658663-664$.

117 Ibid.

118 Ibid.

119 Mpedi 2012 Inaugural Address 2; Creutz "Survivors' Pensions and Death Benefits: Current Issues and Future Perspectives" 199144 International Social Security Review 95.

120 Olivier and Mpedi The Complementary Role of Formal and Informal Social Security in Extending Social Protection: A South African Perspective 3. 
nevertheless able to benefit from such schemes. It is important to state that the definition of "dependant" in the various social insurance schemes is not consistent. ${ }^{121}$ Thus leading to a situation where certain children under one scheme are eligible, whilst being ineligible under the other. Sadly though, posthumously-conceived children are not expressly included under any social insurance scheme as being eligible for survivors' benefits. ${ }^{122}$

\section{The Compensation Fund ${ }^{123}$}

The Compensation Fund provides compensation in the form of medical care or benefits to workers who are injured during the course and scope of employment, or become ill due to their work, including funding for the rehabilitation of disabled workers. ${ }^{124}$ This fund also pays benefits to the families of workers who have died on the job. Contribution to this fund is mandatory in the formal economy because the Compensation Fund derives its revenue from levies paid by employers on the basis of the annual earnings of their employees. ${ }^{125}$ In the event of an accident, injury or disease, an employee will be paid out on the basis of its earnings and the risks associated with the type of work or profession. This is known as assessment fees. ${ }^{126}$ It is important to note that these assessment fees may increase or decrease according to an employer's accident costs.

If an employee incurs an accident or is diagnosed with a work-related disease, the employee or their dependants will be entitled to compensation by COIDA. ${ }^{127}$ An accident is defined by COIDA as a personal injury, an illness or the death of the employee during the course of his/her employment. An occupational disease is defined as a disease that has arisen out of and in the course of employment. ${ }^{128}$ Where an employee is guilty of serious and wilful misconduct which causes an accident, such an employee will forfeit his/her entitlement to compensation unless: the accident results in serious disablement, ${ }^{129}$ or the employee dies as a result of the accident, leaving a dependant wholly financially dependent on him. ${ }^{130}$

The Compensation Fund operates on a no-fault system, which means that in the event of an injury or disease, amongst others, the employee is entitled

121 Olivier in Olivier, Smit and Kalula (eds) Social Security: A Legal Analysis 309; Mpedi 2012 Inaugural Address 3.

122 Mpedi 2012 Inaugural Address 7.

123 The Compensation Fund is established in terms of the Compensation for Occupational Injuries and Diseases Act 130 of 1993 (COIDA).

124 Preamble of the Compensation for Occupational Injuries and Diseases Act (COIDA).

125 Brockenhoff "A Review of the Development of Social Security in South Africa: Monitoring the Progressive Realization of Socio Economic Rights Project" Studies in Poverty and Inequality Institute 201318 http://spii.org.za/wp-content/uploads/2014/01/Working-Paper6 Social-Security-policy-review.pdf (accessed 2014-11-06).

126 S 80 of COIDA.

$127 \mathrm{~S} 1(\mathrm{XXX})$ of COIDA.

$128 \mathrm{~S} 1$ (xxix) of COIDA.

$129 \mathrm{~S} 22(3)(\mathrm{a})(\mathrm{i})$ of COIDA.

$130 \mathrm{~S} 22(3)(\mathrm{a})(\mathrm{ii})$ of COIDA. 
to compensation without having to prove any other party was at fault for the accident. ${ }^{131}$

This Fund provides benefits to employees or their dependants for workrelated injuries or occupational diseases, which are financed through employer contributions. ${ }^{132}$

Benefits are payable to children. A child is explained as follows:

"a child of any such relationship is included as a dependant, as well as a posthumous child, 133 a step-child, an adopted child, an extra-marital ${ }^{134}$ child or a foster child. A very wide range of children is thus covered in order to include any other child, even if there is no relationship of legal dependency, if the child was living with the deceased". ${ }^{135}$

A very important legal distinction must be made between a posthumous child and a posthumously-conceived child. A posthumous child is a child who is conceived during the lifetime of the employee but is born subsequent to its death. On the other hand, a posthumously-conceived child is both conceived and subsequently born after the death of the employee. Based on this distinction, one may elect to infer that posthumously-conceived children are tacitly protected, but in all reality COIDA does not expressly provide for this class of children, whereas posthumous children are indeed expressly provided for.

Thus based on the distinct difference between these two classes of children, it is clear that posthumously-conceived children are excluded from the category of children who are deemed to be eligible "children" to which survivor's benefits may be payable. Furthermore, these children are further deemed ineligible due to not being alive and living with the employee at the time of his or her death. Despite COIDA being enacted to provide a financial safety net for the employee or his dependants in the event of his death during the course and scope of his business, it seems as if a posthumouslyconceived child of such an employee will sadly be marginalized.

131 The Compensation Fund National Treasury Preliminary Report 2nd Draft provides that "the no-fault system of compensation allows the employee to claim compensation without having to sue the employer" $3 \mathrm{http}: / / \mathrm{www}$.treasury.gov.za /publications/other/ssrr/ Session\%200ne \%20Papers/Compensation\%20Fund\%20Project\%202nd\%draft.pdf (accessed 2015-05-23).

132 Mpedi, Kalula and Smit "Extending Social Security Coverage to the Excluded and Marginalized: Perspectives on Developments in South Africa" 2013 International Social Security Association Social: Security Coverage Extension in the BRICS A Comparative Study on the Extension of Coverage in Brazil, the Russian Federation, India, China, South Africa (ISSA) 138

133 S 1 (d) of COIDA.

134 Ibid.

$135 \mathrm{~S} 1(\mathrm{~d}-\mathrm{e})$ of COIDA further provides for both children over and under the age of 18 . A child over the age of 18 years of the employee or of his or her spouse, who in the opinion of the Director-General was acting in the place of the parent; De Villiers and Giese A Review of Children's Access to Employment-based Contributory Social Insurance Benefits (2008) 33. 


\section{The Unemployment Insurance Fund ${ }^{136}$}

Unemployment insurance system is a system offering subsistence income to eligible recipients to alleviate the harmful economic and social loss effects of income loss due to unemployment shocks. The unemployment insurance is prevalent in many industrialized economies in the world, but much less so in developing countries. ${ }^{137}$

With the onset of democracy in 1994, the statute governing unemployment insurance was repealed. ${ }^{138}$ The Unemployment Insurance Act $^{139}$ came into effect on April 1, 2002. ${ }^{140}$ Administratively, the monies are collected by the Unemployment Insurance Fund, which falls under the auspices of the Department of Labour. The Unemployment Insurance Fund system plays a key role in South Africa's social-security architecture; particularly since it is the South Africa's only arm for the unemployed - more specifically, the portion of the unemployed who were previously employed. ${ }^{141}$ Participation in the unemployment-insurance scheme is compulsory in South Africa. ${ }^{142}$ The Unemployment Insurance Fund is used to provide income-replacement benefits, including those for unemployment, illness, maternity, adoption and dependency. ${ }^{143}$ The Fund is operated as an insurance scheme and is fully funded by the employee and employer contributions. ${ }^{144}$ Coverage extends to employees who are or were contributors as defined in the Unemployment Insurance Act. ${ }^{145}$

In terms of the Unemployment Insurance Act;

"dependant's benefits are payable to the spouse or life partner of a contributor if he or she makes application 'within six months of the death of the contributor'. ${ }^{146}$ If there is no surviving spouse or life partner, or no application by such a person is made within six months of the contributor's death, ${ }^{147}$ any

136 The legislative framework for unemployment insurance in South Africa is provided for in two pieces of legislation: the Unemployment Insurance Act 63 of 2001 and the Unemployment Insurance Contributions Act 2 of 2002.

137 Bhorat, Goga and Tseng "Unemployment Insurance in South Africa: A Descriptive Overview of Claimants and Claims" 2013 Development Policy Research Unit, University of Cape Town 5.

138 Bhorat, Goga and Tseng 2013 Development Policy Research Unit, University of Cape Town 6; South Africa has a long history of unemployment insurance with the promulgation of the first Unemployment Insurance Act 30 of 1966 (UIA) during apartheid.

13963 of 2001.

140 With the introduction of the amended act, the original Unemployment Insurance Act 30 of 1966 was repealed with some transitional arrangements.

141 Bhorat, Goga and Tseng 2013 Development Policy Research Unit, University of Cape Town 5.

142 Mpedi, Kalula and Smit 2013 International Social Security Association Social: Security Coverage Extension in the BRICS A Comparative Study on the Extension of Coverage in Brazil, the Russian Federation, India, China, South Africa (ISSA) 141.

143 Bhorat, Goga and Tseng 2013 Development Policy Research Unit, University of Cape Town 5.

144 Payable in terms of the Unemployment Insurance Contributions Act 4 of 2002.

145 Olivier in Olivier, Smit and Kalula (eds) Social Security: A Legal Analysis 306.

$146 \mathrm{~S} \mathrm{30(1)(b)} \mathrm{of} \mathrm{the} \mathrm{UIA} \mathrm{states} \mathrm{that} \mathrm{"an} \mathrm{application} \mathrm{may} \mathrm{be} \mathrm{made} \mathrm{within} \mathrm{six} \mathrm{months} \mathrm{of} \mathrm{the} \mathrm{death}$ of the contributor except that, on just cause shows, the Commissioner may accept an application after the six-month period".

$147 \mathrm{~S} 30(2)(\mathrm{b})$ of the UIA. 
dependant child of a deceased contributor is entitled to the dependant's benefit. ${ }^{148}$ Thus children only qualify if there is no spouse." ${ }^{149}$

The apparently unfounded assumption is that the surviving spouse will look after the child/children and that for this reason the child can only claim if the spouse has not done so. ${ }^{150}$ Posthumously-conceived children are therefore ineligible in any case because children rank lower than the surviving spouse or life partner, thus substantially reducing any prospects of benefiting at all. The glaring reality is that no one can guarantee the surviving spouse or life partner with the care of the deceased's living children, let alone those that might be born sometime in the future. ${ }^{151}$ The second reason for deeming posthumously-conceived children automatically ineligible for survivors' benefits is the six months' time limit prescribed by the UIA for claiming. ${ }^{152}$ Not only is the general gestational period nine months, assuming that the Commissioner would contemplate waiting indefinitely for such a child to be born a "just cause", seems rather doubtful. ${ }^{153}$ Lastly, the simple fact that stepchildren and unborn children are expressly excluded by this Act, ${ }^{154}$ lends one to conclude that an urgent legislative revamp is needed.

\section{The Mines and Works Compensation Fund ${ }^{155}$}

Since the discovery of the major gold deposits on the Witwatersrand in 1886, gold mining has shaped South Africa for better and for worse. ${ }^{156}$ South African mines have produced roughly forty per cent of all gold ever mined on the planet. ${ }^{157}$ Mine work is inherently dangerous and conditions in South Africa are particularly risky. Here exist the world's deepest gold mines and very narrow ore bodies, which have exposed workers to serious health hazards, including high concentrations of silica dust. ${ }^{158}$ The relevance of providing this general background information is that, due to the high number of deaths and illnesses caused by silicosis, ${ }^{159}$ a series of

$148 \mathrm{~S} 30(2)(\mathrm{a})$ of the UIA.

149 De Villiers and Giese A Review of Children's Access to Employment-based Contributory Social Insurance Benefits 48.

150 Olivier in Olivier, Smit and Kalula (eds) Social Security: A Legal Analysis 307.

151 Mpedi 2012 Inaugural Address 6.

152 Ibid.

153 Ibid.

154 De Villiers and Giese A Review of Children's Access to Employment-based Contributory Social Insurance Benefits 48.

155 The Mines and Works Compensation Fund is established in terms of the Occupational Diseases in Mines and Works Amendment Act 208 of 1993 (ODIMWA).

156 Boyko, Darby, Goldberg and Milin "Fulfilling Broken Promises: Reforming the Century-old Compensation System for Occupational Lung Disease in the South African Mining Sector" 2013 Yale Global Health Justice Partnership 10.

157 "Chasing Gold: Then and Now" American Museum of Natural History http://www.amnh.org/exhibitions/past-exhibitions/gold/incomparable-gold/chasing-gold-thenand-now (accessed 2013-04-08).

158 McCulloch "Hiding a Pandemic: Dr. G.W.H. Scheepers and the Politics of Silicosis in South Africa" 2009 Journal of Southern Africa Studies 35.

159 Silicosis is an inflammatory and fibrotic lung disease that also hinders the body's ability to control the mycobacteria that cause tuberculosis. 
commissions and laws regulating dust levels in the mines and establishing mechanisms for workers' compensation, including for silicosis, was led. ${ }^{160}$ This resulted in certain diseases being compensated under the Occupational Diseases in Mines and Works Act of 1973, due to the nature of the mining industry.

The Mines and Works Compensation Fund is financed by the levies on the owners of controlled mines. The Fund provides for the management of permanent, irreversible, incurable conditions. ${ }^{161}$ The Mines and Works Compensation Fund provides compensation to past and present miners who have contracted lung-related diseases, including silicosis and tuberculosis, pneumoconiosis, permanent obstruction of airways and progressive systematic sclerosis, during the course and scope of their employment. ${ }^{162}$

What is important to note is that a "dependant" is not defined in the ODIMWA. ${ }^{163}$ The Act provides the Commissioner with the discretion to designate who shall be regarded as a dependant. ${ }^{164}$ Act:

In terms of the Occupational Diseases in Mines and Works Amendment

"the Commissioner's practice is to make payment of the lump sum exclusively

to the widow, if alive. If there is no widow, it is practice of the Fund to pay to

legal dependants who were also factually dependent on the deceased, and

thereafter to any other de facto dependants". ${ }^{165}$

Posthumously conceived children are ineligible under ODIMWA because they rank lower than the widow, to whom payment is made "exclusively". They also fail to successfully pass the dependant requirements, due to neither being legally nor factually dependent on the income of the deceased at the time of his death. Sadly though, despite the ODIMWA making express provision for legal, factual and de facto dependants, ${ }^{166}$ it is doubtful that the exclusion of posthumously-conceived children will pass constitutional and

160 McCulloch "Counting the Cost: Gold Mining and Occupational Disease in Contemporary South Africa" 2009 African Affairs 108.

161 The Compensation Fund: Preliminary Report $2^{\text {nd }}$ Draft The National Treasury http://www.treasury.gov.za/publications/other/ssr/Session\%20OnePapers/Compensation\%2 OFund\%20Project\%202nd\%20draft.pdf (accessed 2014-11-12) 3.

162 Mpedi, Kalula and Smit Social Security Coverage Extension in the BRICS A Comparative Study on the Extension of Coverage in Brazil, the Russian Federation, India, China, South Africa (Report, International Social Security Association (ISSA) 2013) 139.

163 De Villiers and Giese A Review of Children's Access to Employment-based Contributory Social Insurance Benefits 43.

$164 \mathrm{~S} 80(4)$ of the ODIMWA.

165 De Villiers and Giese A Review of Children's Access to Employment-based Contributory Social Insurance Benefits 43.

166 De Villiers and Giese A Review of Children's Access to Employment-based Contributory Social Insurance Benefits 44 provides that "if there is no widow, it is practice of the Fund to pay legal dependants who were also factually dependant on the deceased, and therefore to any other de facto dependants. This would include all biological and adopted children of the deceased, or children placed formally under his or her foster care, as well as any ancestral relations of the deceased. Benefits are distributed equally between these people. Stepchildren, informal foster children, unborn children, posthumous children or any other child that the deceased did not owe a legal duty of support to, are not considered unless there are no legal dependants". 
equality muster, given the constitutional prohibition on unfair discrimination based on birth, marital status, and sexual orientation. ${ }^{167}$

\section{The Government Employees Pension Fund}

The Government Employees Pension Fund is governed by the Government Employees Pension Law (1996). Its core business is to manage and administer pensions and other benefits for Government employees in South Africa. ${ }^{168}$ The Government Employees Pension Fund is a defined-benefit pension fund, meaning that all pensions and related benefits are guaranteed and that members will never receive less than the benefits for which they qualify. The Government Employees Pension Fund manages both contributory and non-contributory benefits. ${ }^{169}$

Contributory benefits are based on the contributions that the members and their employers pay during each member's period of employment in Government service. Based on these contributions, each member qualifies for certain guaranteed benefits on retirement, resignation, ill health, death or discharge. ${ }^{170}$

Non-contributory benefits differ from contributory benefits in that they are not based on member and employer contributions, but are funded by the Government. These include special pensions, post-retirement medical benefits, injury on duty payments, military pensions and pensions for former State Presidents, Parliamentary office-bearers, judges and magistrates.

Both a spouse ${ }^{171}$ and children are beneficiaries in terms of the Government Employees Pension Fund.

In terms of the Government Employees Pension Fund:

"a child includes a natural or adopted child of the member or pensioner, under the age of 18, or a full time student under the age of 22, or any adult child who is disabled and factually dependant on the deceased. It includes extramarital children, but does not include foster children or stepchildren. ${ }^{172}$ An orphan child whose parents, either natural or adopted, are deceased. If there is a spouse and orphans by a deceased spouse, the orphans are eligible for the deceased spouse's portion". ${ }^{173}$

The Government Employees Pension Fund has many weaknesses in that, despite both a spouse and child being deemed beneficiaries, a couple of

167 Olivier in Olivier, Smit and Kalula (eds) Social Security: A Legal Analysis 303.

168 Government Employees Pension Fund "Government Pensions Administrations Agency Member Guide" http://www.gov.za.sites/www.gov.2d/files/Government\%20 Employess\%20 Pension\%20Fund\%20Members\%Guide a.pdf (accessed 2014-10-28) 4.

169 Government Employees Pension Fund "Government Pensions Administrations Agency home page" http://www.gov.za.sites/www.gov.2d/files/Government\%20Employess\%20 Pension\%20Fund\%20Members\%Guide_a.pdf (accessed 2014-10-28).

170 Ibid.

171 Rule 1(25) of the Government Employees Pension Fund provides that a spouse includes a customary law marriage recognised in terms of the Recognition of Customary Marriages Act, a life partner or partner in a religious marriage.

172 Rule 1(8) of the Government Employees Pension Fund.

173 De Villiers and Giese A Review of Children's Access to Employment-based Contributory Social Insurance Benefits 55. 
categories of children have expressly been excluded. ${ }^{174}$ This ultimately provides an impression that this particular fund is constitutionally insensitive to the directives provided in that a child's best interests and welfare is paramount in all matters concerning them. Not only does the Fund not make provision for posthumously-conceived children, but posthumous children are also excluded. Posthumously-conceived children are thus clearly not eligible for survivor benefits in terms of this Fund either. ${ }^{175}$ The exclusion of both categories of children leads to the conclusion that the Fund was created at a time when such children could not have possibly been foreseen, thus justifying the urgent need for a comprehensive overhaul of the current socialsecurity survivors' benefits-legislative framework.

\section{Social assistance}

"Social assistance" can be defined as a scheme which is generally financed from the general revenue of the country rather than individual contributions, with statutory scales of benefits adjusted according to a person's means. ${ }^{176}$ The primary goal of social assistance is to alleviate poverty. ${ }^{177}$

Social grants are used for social assistance in South Africa, which are non-contributory and means-tested benefits provided by the State to groups who are unable to provide for their own needs, such as people with disabilities, elderly people, parents and children. ${ }^{178}$

\section{Relevant private-law rule}

\section{Marriage dissolved by death}

The traditional definition of marriage is a "legally-recognized life-long voluntary union between one man and one woman to the exclusions of all other persons." 179 Death dissolves a marriage, but the law also provides for various dissolutions by an order of the High Court. ${ }^{180}$ Thus technically, no child/children can be conceived and subsequently born out that marriage, because the marriage does not legally exist anymore. Posthumous conception has created modern legal complications. Nevertheless, the law must catch up with medical developments to ensure that these children are adequately provided for.

174 Stepchildren and foster children.

175 This position is further aggravated by the fact that the Government Employees Pension Fund Government Pensions Administrations Agency Member Guide 12 explicitly states "if you have children, it is important to register them with GEPF". This assertion clearly implies that only children who are either born or conceived at the time of the member's death will be covered.

176 Van der Berg "The Means Test for Social Assistance Grants and its Recent Evolution" 2001 Social Work 125.

177 See fn 116 above.

178 White Paper for Social Welfare Government Notice 1108 in Government Gazette 18166 of 1997-08-08 (White Paper for Social Welfare).

179 Cronje, Barnard and Olivier The South African Family Law (2004) 149.

180 Ibid. 


\section{RELEVANT FOREIGN EXPERIENCES WITH THE SOCIAL-SECURITY ENTITLEMENTS OF POSTHUMOUSLY-CONCEIVED CHILDREN}

\section{Introduction}

With the emergence of modern reproductive technology, freedom of choice has not guaranteed freedom from legal confusion. ${ }^{181}$ The recurring question as to whether posthumously-conceived children are entitled to socialsecurity survivor's benefits, amongst other legal rights, has indeed brought about bounds of international confusion. This international confusion has stemmed from the fact that the current statutory and common-law legal framework of many jurisdictions "revolves around the idea that the parentchild relationship is created by a man and woman having sexual intercourse and a child being born as a result". ${ }^{182}$ However, with the rapid advances in reproductive technology, this concept is clearly antiquated and is now in drastic need of reform, primarily because assisted reproductive technology has made, and can make, a deceased man "fertile" for another "lifetime". ${ }^{183}$ As such, it is not only South Africa within the international legal community that has unsatisfactorily responded to the challenges presented by this class of children, but rather, it is an international "crisis" where a lack of legal uniformity or clarity seems to exist in many jurisdictions.

Assisted reproductive technologies are relatively new in South Africa, with the first in vitro fertilization "test-tube" baby being born in 1984. ${ }^{184}$ Internationally though, assisted reproductive-technology practices date considerably further back, and the possibility of conceiving human beings by artificial means has a long history. ${ }^{185}$ The first documented application of artificial insemination in a human was in the 1770 s by John Hunter, which has been titled in medical history as the "the founder of scientific surgery". 186 "By 1986, it was estimated that as many as 20000 women were artificially inseminated each year in the United States." 187 Whilst on the $25^{\text {th }}$ July 1978 , England was the first country in the world to see the first birth of a "test-tube" baby, Louise Joy Brown, as a result of in vitro fertilization. ${ }^{188}$ The first

181 Minor "Posthumously Conceived Children and Social-Security Survivor's Benefits: Implications of the Ninth Circuit's Novel Approach for Determining Eligibility" in GillettNetting v Barnhart 200535 Golden Gate University School of Law Review 85.

182 Schleringer "Assisted Human Reproduction: Unsolved Issues in Parentage, Child Custody and Support" 200561 Journal of Missouri Bar 22.

183 Leach "Perpetuities in the Atomic Age: The Sperm Bank and the Fertile Decedent" 1962 American Bar Association Journal 942.

184 Professor Thinus Kruger's research and fertility treatment resulted in the birth of South Africa's first "test-tube" baby www.aevitas.co.za/team-prof-thinus-kruger-html (accessed 2014-08-12).

185 Alberta Law Reform Institute "Report for discussion 23: Succession and Posthumously Conceived Children" 2012233.

186 Ombelet and Van Robays "History of Human Artificial Insemination" 2010 Facts, views and visions in ObGyn Monograph 2.

187 Jhordan C v Mary K 224 Cal. Rptr 530, 532 n.l (Cal Ct App 1986).

188 See fn 3 above. 
scientific inklings of cryopreservation were in 1949, when it was first made possible to freeze sperm for later use. ${ }^{189}$

Based on the information provided, it is easy to ascertain that a substantial number of years have lapsed since assisted reproductive technologies were first developed, and subsequently the possible number of posthumously-conceived children born as a result of these technologies internationally is also substantial. From a South African social security law perspective, the general assumption would be that the USA and the UK have legal frameworks that exceptionally regulate these children's entitlement to social-security survivor's benefits, inheritance rights, legal capacity, etcetera. Furthermore, it could be assumed that both these countries would have a legal framework that other countries may use as a yardstick when initially dealing with the challenges presented by this class of children. Though this statement is true to some extent, both countries' social-security laws in regard to posthumously-conceived children are indeed filled with inconsistencies. The possible reason being that posthumous conception and posthumously-conceived children have been and keep raising many thorny and troubling questions which the Courts are still grappling with. ${ }^{190}$ This is clearly reflected by the legal battles in countries such as the United States of America, Australia, the United Kingdom and France. ${ }^{191}$

Other developed nations, such as Israel, have formulated policies dealing adequately with posthumous conception and posthumously-conceived children that the United Kingdom and the United States could implement. ${ }^{192}$ What is important to note though, is that both the USA's and UK's entire social-security legal systems pertaining specifically to posthumouslyconceived children's entitlements to survivor benefits, as opposed to mere policies here and there, are nevertheless still strides and strides more extensive and advanced when compared to other nations. Thus they rendered their legal systems as better yardsticks for South Africa.

189 Greenfield "Dad Was Born a Thousand Years Ago? An Examination of Post-mortem Conception and Inheritance, with a Focus on the Rule against Perpetuities" 20078 Minnesota Journal of Law, Science and Technology 277.

190 Ewelukwa "Posthumous Children, Hegemonic Human Rights, and the Dilemma of Reform Conversations Across Cultures" 200819 University of Arkansas School of Law Hastings Women's Law Journal 241.

191 Ibid.

192 In Droghazi 200583 Washington University Law Quarterly (WASHULQ) 1602 reference is made to other countries which have also addressed posthumous conception, for eg, Germany, Sweden, Canada and Australia. Western Australia prohibits the use of someone's gametes after death, and requires any existing gametes be destroyed within one year of the donor's death. Conversely, Israel allows a surviving wife to use embryos, created with her husband's sperm, for up to one year after his death, regardless of his consent. If the wife dies, Israel does not allow another woman to use the embryo. 


\section{Cases from the United States of America addressing the rights of posthumously-conceived children to inherit in the social security context}

The majority of case law dealing with a posthumously-conceived child's right to inherit or obtain benefits emerges when a surviving spouse tries to obtain social security survivor's benefits for that child. ${ }^{193}$ Despite the existence of the test under social security being based on whether a child would inherit under state intestate law and the Social Security Act, ${ }^{194}$ as well as being there to aid the Courts in their decision-making, the question of posthumously-conceived children's eligibility for survivor benefits has been marred by conflicting results. It is very important to note that these two aids are interdependent, in that the American Social Security Administration follows the intestate succession in the particular State where the child resides. ${ }^{195}$ Hence, irrespective of whether the underlying action may be for social-security benefits, the legal analysis for deeming a child eligible for survivor's benefits under State law is the same as determining if a posthumously-conceived child can inherit under intestacy law. ${ }^{196}$

Another aid utilized by the courts when deciding on a posthumouslyconceived child's entitlement for social security survivors' benefits is the definition of "child" in the Social Security Act. The unfortunate thing though, is that sections $416(\mathrm{e})$ and $416(\mathrm{~h})$, which are both found in the Act, offer two different definitions for a "child".

Section 416(e) defines "child" as the "the child or legally adopted child of an individual." 197 Posthumously-conceived children generally fit into this broad definition, due to the tendency of paternity not being disputed. ${ }^{198}$ Alternatively, Section $416(\mathrm{~h})$ uses narrower categories to define who may qualify as a child. ${ }^{199}$ Furthermore, subsection $2 \mathrm{~A}$ indicates that the Act shall apply state-intestacy laws to determine whether an applicant is a "child" of the deceased parent. Simply stated, if the applicant would be able to inherit property from the deceased parent in the state of the parent's domicile at death, then the applicant qualifies as a child for purposes of the subchapter.

Not only are sections $416(\mathrm{e})$ and $416(\mathrm{~h})$ different, but what further perpetuates the issue is that it is unclear from the text how Congress intends

193 Naguit 200974 Missouri LR 895.

194 Social Security Act Amendments of 1939 (hereinafter Social Security Act).

195 Ibid.

196 Ibid.

197 S 416(e) of the Amendments Act. This broad definition also includes the stepchildren, grandchildren, and step-grandchildren who meet certain conditions listed in subsections (e)(2) and (e)(3).

198 Kennedy 201354 Boston College LR 827; Capato I, 631 F.3d 627 held that the biological offspring of a decedent and his widow clearly fit $S 416(\mathrm{e})$ 's definition.

199 S 416(h)(2)(B)-(3) of the Social Security Amendments Act. According to these subsections, an applicant is a child if: (1) the applicant's parents participated in a marriage ceremony that would have been valid for a legal impediment; (2) the insured acknowledged parentage in writing; (3) a Court decreed the insured to be the applicant's parent before the insured's death; (4) a Court ordered the insured to support the child because the insured is the applicant's parent; (5) the Commissioner of Social Security finds satisfactory evidence of parentage, and the deceased parent had lived with or supported the applicant while alive. 
for these two sections to interact. ${ }^{200}$ Despite this lack of clarity being somewhat harmless in most cases, it does become problematic when a posthumously conceived child applies for benefits, ${ }^{201}$ because, unlike other children, posthumously-conceived children often fit the definition of section 416(e) but not section 416(h). ${ }^{202}$ However, none of the additional criteria in subsection (h) applies for children conceived posthumously. ${ }^{203}$ As such, whether posthumously-conceived children are indeed eligible to inherit under a respective State's intestacy laws, will in turn be the deciding factor as to whether these applicants are "children" under section 416(h). ${ }^{204}$ Besides the intestacy-law aspect and the definitions provided in sections 416(e) and (h) of the Act, ${ }^{205}$ key aspects in establishing eligibility have been identified during cases in which posthumously-conceived children sought socialsecurity survivor benefits. Furthermore, the key principles that could yield important lessons for the current South African social security survivors'benefits system will be deduced from each matter. All relevant case law in which these aspects where identified, will be discussed below.

\section{Hart $v$ Shalala}

The question of whether posthumously-conceived children had a right to social security survivor benefits under Louisiana's intestacy laws was addressed in the early Hart $v$ Shalala case. ${ }^{206}$ Unfortunately though, despite the matter coming before various social-security administrations and being heard by the U.S.A. District Court for the Eastern District, the issue of whether Judith could adequately inherit under intestacy law was never

200 Ibid.

201 Kennedy 201354 Boston College LR 827; The Court in Gillett-Netting, 371 F.3d shared the same sentiments and held at 595, 596 that "The Social Security Act ... (does not make) clear the rights of children born posthumously".

202 See fn 199 above.

203 In Shafer 641 F.3d 53 the Court held that a marriage ends at death, eliminating the first possibility, and the other four possibilities required the deceased to have performed some action after the child's birth.

204 Kennedy 201354 Boston College LR 828 see (n 192) above. S 416(h).

205 See fn 197 and fn 199 above.

206 In Hart v Shalala No 94-3944 (E.D. La. 1994), Judith's mother filed for social security survivor's benefits for her child, who was conceived by gamete intrafallopian transfer (GIFT) and born twelve months after the death of her father. The Social Security Administration denied the claim on the ground that the child was not the father's legal child. The Administration first reasoned that the child was not a qualified heir under Louisiana law because she was neither alive at the time of her father's death nor was she born 300 days within his death. Second, the child was also considered illegitimate because she was born more than 300 days after her parents' marriage had ended (upon the death of her father) and paternity was not proved within the statutorily required period. Third, she was unable to ever prove paternity because her father had not acknowledged her as his child before he died.

Hart appealed the administration's denial of benefits. Following a de novo review, the Administration Law Judge awarded the survivor's benefits to both the child and her mother, based on a biological connection between the child and her deceased father. Following an appeal by the Administration of the Administration Law Judge's decision, the Appeals Council of the Administration accepted that the posthumously-conceived child was the biological child of the father, but it overturned the decision of the Administration Law Judge on the ground that the child was not dependent on her father at the time of his death. 
settled, ${ }^{207}$ which was unsatisfactory. This was due to the Federal District Court never reaching a decision because the Social Security Commissioner settled the case on public-policy grounds, ${ }^{208}$ by awarding benefits. ${ }^{209}$ The Social Security Administration ultimately reversed its position in order to avoid a test case on the constitutional issues raised. ${ }^{210}$ Furthermore, upon awarding benefits, the Social Security Commissioner stated that the resolution on the issue "should involve the executive and legislative branches, instead of the courts." 211

\section{Hart v Charter}

The Hart $v$ Charter case in many respects is similar to the Hart $v$ Shalala case. ${ }^{212}$ What makes the Charter case more significant is that, irrespective of the fact that the decedent had given express consent for any posthumous conception and thus a clear intent to support any posthumously-conceived child, the Social Security Appeals Council nonetheless determined that a posthumously conceived child was not entitled to benefits. ${ }^{213}$ Nancy Hart's daughter argued that this verdict was unconstitutional and applied for an appeal to the District Court. ${ }^{214}$ Whilst on appeal, the Social Security Administration again reversed its verdict, dismissed the case and awarded social security survivor benefits to Nancy Hart's daughter. ${ }^{215}$ Furthermore, just like in the Hart $v$ Shalala case, ${ }^{216}$ the Commissioner made a plea that the concerns raised by the issue should be decided by the executive and the legislative branches and not the Courts. ${ }^{217}$

207 Star "A Matter of Life and Death: Posthumous Conception" 2004 Louisiana LR 629.

208 Minor in Gillett-Netting v Barnhart 200535 Golden Gate University School of Law Review 94.

209 Droghazi 200583 Washington University Law Quarterly (WASHULQ) 1603.

210 Hart $v$ Shalala supra 228.

211 Hart $v$ Shalala supra 255, 256.

212 In Hart v Charter 79 F.3d 559 (C.A. 7 Ind 1996): In 1991, Nancy Hart conceived a daughter using the sperm of her husband who had died three months earlier. The Louisiana intestacy law required that a child be alive or born 300 days of the death of the decedent in order to be entitled to inherit. Hart, who was born more than a year after her father's death, was not legally considered an heir to his estate. Further, Hart was unable to prove paternity or that she was legitimate under the State's laws. In spite of this, at the initial hearing Hart was awarded survivor's benefits, based on the fact that she was Mr Hart's biological child. The hearing officer further considered evidence that Mr Hart had acknowledged the possibility of posthumous conception by his wife and assigned the rights to his sperm to her. The officer concluded that this indicated an intent by Mr Hart to support any posthumously-conceived child and that she therefore be awarded benefits. On appeal, the Social Security Appeals Council disagreed, and reversed the award stating that the hearing officer did not base the award of benefits on the relevant State law. The Council concluded that the child was not dependent on Mr Hart, and therefore not entitled to survivor's benefits.

213 Salmon "Determining the Inheritance Rights of Posthumously Conceived Children" 200738 New England School of Law (Advanced Legal Research Paper) 5 http://www.nesl.edu/ research/rsguides/karen_salmon.htm (accessed 2014-03-06).

214 Ibid.

215 Wollwage-Rymut "Has Science Outsmarted Social Security? Posthumously Conceived Children and Survivor's Benefits" 201138 Chicago-Kent College of Law Illinois Institute of Law 9.

216 See fn 206 above.

217 Hart v Shalala supra 255, 256. 
As the earliest cases that came before the Courts where posthumouslyconceived children sought survivors' benefits, the key principles from both the Shalala and Charter matters circulate around the fact that the lack of an expressly consistent piece of legislation, regulating the rights and eligibility of this class of children, ultimately led to a number of appeals and unsatisfactory decisions. Firstly, this assertion is proved by that fact that despite the deceased's clear intention being proved in the Charter case, entitlements were still denied because the legislation was not clear regarding the eligibility of posthumously-conceived children as children. Secondly, the need for clear legislation is proved in that in both matters, awards were finally and only given in order to avoid constitutionally-challenged test cases. The most important lesson to be learned is that in both matters the Commissioners made a plea for the legislative and executive branches to be more involved and promulgate the needed laws to regulate posthumouslyconceived children, due to the concerns and complicated issues raised by them. Thus, the South African legislature can learn from these cases that simply "waiting it out" or "ignoring" the existence of these children is neither satisfactory nor legally fair. Posthumously-conceived children need to be expressly incorporated into the definition of who a child is.

\section{Woodward v Commissioner of Social Security}

The most noteworthy aspect of the Woodward case was that not only was more emphasis, ${ }^{218}$ for the first time really, placed on the need for clear and unequivocal evidence of the decedent's consent, ${ }^{219}$ but that the Court achieved its aim to examine the Massachusetts intestacy rule and announce a balancing test. 220 It is one that many Courts have modelled their conclusions on, where State intestacy laws do not address posthumouslyconceived children. ${ }^{221}$

In Woodward $v$ Commissioner, the Massachusetts Supreme Court was faced with answering the following certified question:222

218 In Woodward v Commissioner of Social Security 760 n.e.2d 257 (Mass. 2002) the involved twins conceived using the frozen sperm of a deceased cancer patient. Upon discovering that he had leukaemia in 1993, Warren Woodward and his wife, who were childless, feared chemotherapy would leave him sterile. Thus, before he underwent a bone-marrow transplant, the couple deposited his sperm with the hope that they could use it in the future whether or not he survived. He died eight months later. Two years later, his wife, Lauren Woodward, gave birth to twin girls. The Social Security Administration rejected the mother's claims for benefits, for she had not established that the twins were her husband's "children" within the meaning of the Act and therefore they could not inherit under Massachusetts intestacy law. The twins' mother pursued her claim in the United States District Court for District of Massachusetts.

219 In Woodward v Commissioner of Social Security supra 269, 270 the Court placed a need for clear and unequivocal evidence of the decedent's consent in efforts to best support the legislature's intent to prevent fraud, due to the fact that frozen semen could remain viable for up to ten years, and that a person who donates genetic material may have had no desire to conceive posthumously.

220 Woodward v Commissioner of Social Security supra 264, 265.

221 Wollwage-Rymut 201138 Chicago-Kent College of Law Illinois Institute of Law 12.

222 Woodward $v$ Commissioner of Social Security supra 261; Droghazi 200583 Washington University Law Quarterly (WASHULQ) 1605. "Woodward did not rule on the factual circumstances because it was answering a question certified from the United States District 
"If a married man and woman arrange for sperm to be withdrawn from the husband for the purpose of artificially impregnating the wife, and the woman is impregnated with that sperm after the man, her husband, has died, will the children resulting from such pregnancy enjoy the inheritance rights of natural children under Massachusetts law of intestate succession?"223

In reviewing this question, the Court analysed the facts of the case and as such dug into the Massachusetts State intestacy laws by examining the facts by way of a balancing test. ${ }^{224}$ The Court, in order to "effect the legislature's over-all purposes," emphasized that its role was ultimately to "balance and harmonize" the competing interest of the child, the State and the deceased. ${ }^{225}$

(i) That posthumously-conceived children would need to obtain a judgment of the best interest of the child, the Court concluded that the State is firmly dedicated to protecting the rights of all children "regardless of the accidents of their births". ${ }^{226}$ Furthermore, the Court stated that it believed it would be irrational for the legislature to deny rights and protections to posthumously-conceived children. ${ }^{227}$

(ii) The State's interest in the orderly administration of estates, the Court held paternity to enable them to inherit, because this class of children was non-marital due to being conceived after the death of their father. ${ }^{228}$

(iii) As to the reproductive rights of the deceased parent, the Massachusetts Supreme Court held that posthumously-conceived children could inherit from the deceased if Mrs Woodward could prove the following: the genetic relationship between Mr Woodward and the twins, that $\mathrm{Mr}$ Woodward had consented before his death to Mrs Woodward using his stored sperm to reproduce posthumously, and that Mr Woodward had consented before his death to support any child born posthumously. ${ }^{229}$

Court for District of Massachusetts. The question was certified to the Massachusetts Supreme Court because no precedent on this issue had been set yet".

223 Woodward v Commissioner of Social Security supra 257, 259.

224 Woodward $v$ Commissioner of Social Security supra 264, 265. The Massachusetts Supreme Court probed into the State intestacy law by way of a balancing test of "the best interests of children, the State's interest in orderly administration of estates, and the reproductive rights of the genetic parent".

225 Star "A Matter of Life and Death: Posthumous Conception" 2004 Louisiana LR 2004634.

226 Woodward v Commissioner of Social Security supra 261; In Star 2004 Louisiana LR 634, the Court held that "Repeatedly, forcefully, and unequivocally, the Legislature has expressed its will that all children be entitled to the same rights and protections of the law regardless of the accidents of their birth".

227 Woodward v Commissioner of Social Security supra 265-267.

228 Woodward v Commissioner of Social Security supra 266, 267.

229 Woodward v Commissioner of Social Security supra 269; Williams "Over My Dead Body: The Legal Nightmare and Medical Phenomenon of Posthumous Conception through Postmortem Sperm Retrieval" 2012 Campbell LR 187. The Court required the deceased's premortem consent to posthumous reproduction to be "clear and unequivocal," stating that silence or equivocal indications of a desire to be a parent posthumously "ought not to be construed as consent."' (quoting Schiff "Arising from the Dead: Challenges of Posthumous Procreation" 1997 North Carolina LR 901,951. 
The Court suggested a disclaimer for future matters by providing that a time limit might preclude qualifying for inheritance rights, regardless of whether the above conditions were satisfied. ${ }^{230}$

One could observe that the noteworthy aspect of the Woodward decision is that, the Massachusetts Supreme Court disregarded existing paternity and inheritance laws, ${ }^{231}$ but rather concentrated on achieving an "equitous outcome" for posthumously-conceived children.232 The Woodward Court went a step further by firstly protecting the interests of the decedent, by allowing benefits to be given to this class of children only if the decedent had indeed consented to the birth. ${ }^{233}$ The State's interest is also provided for by preventing the indefinite reality attached to such claims through the inclusion of time limits. Currently, the South African social security survivors'-benefits legal system can be viewed as having main consideration for the State's interest. Thus, a satisfactory legislative framework would be one that balanced and comprehensively regulated the various interests involved.

\section{Capato ex rel B.N.C. v Commissioner of Social Security (Capato II)}

The U.S. Supreme Court in the Capato /I matter, ${ }^{234}$ in its efforts to resolve the conflict and inconsistencies caused by the various previous cases, ${ }^{235}$ granted certiorari. ${ }^{236}$ The issue that the Supreme Court had to consider was whether posthumously-conceived children were legally related to their biological fathers, for the purposes of social-security survivor benefits. ${ }^{237}$ More specifically though, the technical question in Capato II was whether section $416(\mathrm{~h})$ provides the exclusive means for proving "child" status under the Social Security laws. ${ }^{238}$ Whilst Karen Capato said "no", the Social Security Administration said "yes".

On May 21, 2012, the U.S. Supreme Court issued a unanimous decision in favour of the Social Security Administration, thus reversing the Appellate Court's decision. ${ }^{239}$ The Court held that the Social Security Administration's

230 Woodward v Commissioner of Social Security supra 272.

231 Disregarded s 416(e) and (h) criteria of what a "child" is for the purposes of the Act, and the Court further disregarded the Massachusetts intestacy laws.

232 Star 2004 Louisiana LR 635.

233 Ibid.

234 Capato ex rel B.N.C. v Commissioner of Social Security (Capato II) 132 S. Ct. 2021 (2012).

235 Namely: Capato ex rel B.N.C. v Commissioner of Social Security (Capato I) 631 F.3d (3 Cir. 2011), Schafer v Astrue 10-1500, 20111378486 (4 ${ }^{\text {th }}$ Cir 2011), and Beeler v Astrue, 651 F.3d 954 (8 $8^{\text {th }}$ Cir. 2011).

236 Capato ex rel B.N.C. v Commissioner of Social Security (Capato II) supra 2027; Edwards "Legal Summaries" 2013 Journal of the National Association of Administrative Law Judiciary 440.

237 Capato ex rel B.N.C. v Commissioner of Social Security (Capato II) supra 2027.

238 Grossman "The Supreme Court on the Social Security Rights of Posthumously Conceived Children: State Law Controls Family Status" 2012 http://verdict.justia.com/2012/05/29/thesupreme-court-on-the-social-security-rights-of-posthumously-conceived-children (accessed 2014-08-07) 3.

239 Dwyer "Inheritance Rights of Posthumously Conceived Children" http//www.cga.ct.gov/ 2012/rpt/2012-R-0240.htm (accessed 2014-03-06) 1. 
interpretation, even if not the only reasonable one, was a permissible one under the Act. ${ }^{240}$

Upon acknowledging that 'the technology that made the twins' conception and birth possible ... was not contemplated by Congress when the relevant provisions of the Social Security Act ... originated (1939), or when amended to read as they now do (1965)", the Court sided with the Fourth and Eighth Circuits and held that the Administration's interpretation of the Act - entitling "biological children to benefits only if they qualify for inheritance from the decedent under State intestacy law, or satisfy one of the statutory alternatives to that requirement" - is "better attuned to the Statute's text and its design to benefit primarily those supported by the deceased wage earner in his or her lifetime". ${ }^{241}$ Hence, the Court determined that using the definition of "child" in section 416(h)(2)(a) furthers the core purpose of the Act. ${ }^{242}$

The Supreme Court then reasoned that Karen's elevation of children of married parents to some category where other criteria for parentage need not be applied, is unwarranted under current law. 243 The Court cited dictionaries, law treaties, and other statutory provisions to suggest that "child" can have different meanings, but many of those meanings, at least today, define "child" without regard to the marital status of the parents. Moreover, the Court questioned whether the twins were indeed the children of married parents. After all, Robert died before they were conceived, and a marriage is legally over when the first spouse dies. ${ }^{244}$

Thirdly, the Court held that reading the Act to rely primarily on State law regarding family status, is consistent with other portions of the Statute and with federal law generally. ${ }^{245}$ Using State law ensured that the Act would cover all ["child"] applicants within Congress's contemplation, while avoiding congressional interference with family relations, an area traditionally within the realm of State law. ${ }^{246}$ The Court also emphasized that "the paths to receipt of benefits laid out in the Act and Regulations ... proceed from Congress's perception of the core purpose of the legislation". ${ }^{247}$ Thus, despite some states explicitly providing intestate inheritance for posthumously-conceived children in their intestacy laws and other States

240 Kennedy 201354 Boston College LR 840.

241 Russo "Intestacy, Dependency, and Social Security, Oh My! An in-depth look at Posthumously Conceived Children" 2013298 Law School Student Scholarship 42.

242 In Edwards 201333 Journal of the National Association of Administrative Law Judiciary 443 , the Court held that "If a child can take personal property from the deceased's estate under intestacy laws, the Court determined it is reasonable to assume that the child will be more likely to be dependent during the parent's life and after the parent's death. Thus, the intestacy laws help to further the overall purpose of the Social Security Act."

243 Grossman http://verdict.justia.com/2012/05/29/the-supreme-court-on-the-social-securityrights-of-posthumously-conceived-children 3. The Court stated that nothing in section 416(e) indicates that Congress meant it to apply to children of married parents but not to those of unmarried parents.

244 Grossman http://verdict.justia.com/2012/05/29/the-supreme-court-on-the-social-securityrights-of-posthumously-conceived-children 4.

245 Ibid.

246 Kennedy 201354 Boston College LR 842.

247 Russo 2013298 Law School Student Scholarship 46. 
not, ${ }^{248}$ the Court held that nonetheless it was "Congress's prerogative to legislate for the generality of cases". ${ }^{249}$ Which it did "by employing eligibility under State intestacy law as a workable substitute for burdensome case-bycase determinations, whether the child was, in fact, dependent on her father's earnings". ${ }^{250}$

Finally, based on these observations, the Court held that the Social Security Administration's long-standing interpretation was reasonable and thus entitled to deference. ${ }^{251}$ Such deference was entitled under Court's precedent in Chevron U.S.A. Incorporation v Natural Resources Defense Council Incorporation. ${ }^{252}$

After considering all these factors, the Supreme Court held that applications for child-insurance benefits, as in this case, must be resolved in reference to State intestacy law. ${ }^{253}$ Therefore, the Court reversed the Third Circuit's decision and remanded for further proceedings consistent with this opinion. ${ }^{254}$

\section{Key lessons from the discussed cases that can be of relevance and value to South Africa}

The greatest lesson that can be taken away is that the need for legislative reform, as opposed to the Court route, is imperative. The issue of whether posthumously-conceived children are entitled to survivors' benefits has been an ongoing legal matter before the U.S.A. judiciary for more than two decades. ${ }^{25}$ The South African legislative branch should see that as an indication of how reformation of eligibility is ultimately a ball in the legislature's court. Justification for this assertion is based on the fact that in several of the discussed cases, the Commissioners and presiding officers in question had called for the legislative and executive branches' intervention. This call for intervention was yielded on the basis that the courts are not sufficiently equipped to handle the particular issues brought about by posthumously-conceived children. If anything, it reinforces the reality that

Kennedy 201354 Boston College LR 842.

249 Russo 2013298 Law School Student Scholarship 46.

250 The acquiescence ruling is only applicable in the Social Security Administration in the Ninth Circuit: Alaska, Arizona, California, Guam, Hawaii, Idaho, Montana, Nevada, Oregon, Washington, and Northern Mariana Islands. The remaining States are to continue examining these cases by utilizing different combinations of the tests in Gillett-Netting, Woodward, etc.

251 Kennedy 201354 Boston College LR 842.

252 See fn 244 above; In Chevron U.S.A. Inc v Natural Resources Defense Council Inc (1984) 467 U.S. 837-838 decision, the Court laid out the general standard for deference to administrative agencies. Deference is appropriate "when it appears that Congress delegated authority to the agency generally to make rules carrying the force of law, and that the agency interpretation claiming deference was promulgated in the exercise of that authority".

253 Edwards 2013 Journal of the National Association of Administrative Law Judiciary 444.

254 Ibid.

255 The first judicial controversy regarding posthumously-conceived children may well have occurred in Louisiana 1994 in the case of Hart v Shalala supra. Banks "Traditional Concepts and Nontraditional Conceptions: Social Security Survivor's Benefits for Posthumously Conceived Children" 1999 Loy. L.A. LR 251. 
courts want to avoid getting involved in governmental-agency decisions when possible. ${ }^{256}$ This lesson is relevant to South Africa because modern reproductive technologies are forever developing, thus laws have to be put in place in order to be on a par with the medical landscape as in yesterday, instead of playing the "wait-and-see" game. Furthermore, this lesson is a valuable one because, if heeded and the legislature reforms the current social-security survivors'-benefits laws instead of waiting for a matter to come before court, it will serve in preventing potentially lengthy, costly, dragged-out court battles.

What can be observed from the discussed cases is that the United States of America has a uniform codified act, the Social Security Act, which provides a definition of what a child is for the purpose of, amongst others, dispute resolution regarding benefit claims. This is commendable and is of value to South Africa in that the legislature should strive to make the current social security legislative framework more uniform, preferably under one codified piece of legislation.

On the downside though, is that despite America possessing this uniform piece of social security legislation, its definition(s) of an eligible child is(are) riddled with inconsistencies. This problem is further perpetuated in that eligibility to social-security benefits are tied to the child's State intestacy laws. ${ }^{257}$ Thus, as in South Africa, nowhere in the American laws are posthumously-conceived children expressly provided for. As such, the Courts have for years not been sure how these definitions and laws are to interplay, if at all. This lack of clarity is of particular importance and relevance, because, despite South Africa not having a uniform piece of legislation, the Republic's social security schemes are scattered and their definition of who a child is are as equally riddled with inconsistency upon inconsistency. Furthermore, South Africa's survivors' benefits fail to expressly provide for posthumously-conceived children.

Thus, as a result of the legislative inconsistencies, the application of State intestacy laws, and the lack of categorical posthumously-conceived specific legislation, the trend in the American judicial system has been and is still to apply outdated laws to a situation that had not been contemplated by Congress when drafting such laws. ${ }^{258}$ As such these outdated laws will always be detrimental to the eligibility of posthumously-conceived children because they all require some sort of dependency that existed during the lifetime of the deceased. Whereas some Courts have been cognizant of the unreasonableness lying in these outdated laws, ${ }^{259}$ and chose to award

256 Edwards 2013 Journal of the National Association of Administrative Law Judiciary 445.

257 Requiring State intestacy laws to dictate the eligibility for a child's survivors' benefits perpetuates the inconsistency dilemma because each State in America has its own Statespecific intestacy laws. Thus where in one State posthumously-conceived children are deemed eligible for benefits, another State can declare this class of children ineligible. This fundamentally does not promote uniformity at all. In re Martin B 841 N.Y.S 2d 207 (NY Sur Ct 2007), the Court suggested "the need for federal initiative to separate federal entitlements from State eligibility requirements".

258 As seen in the precedent setting decision of Capato II (see fn 234).

259 For eg, both the Hart v Shalala supra 324 and Gillett-Netting v Barnhart 231 F courts "did admit that the statutes, although formulated in the past, should look to the future, especially 
benefits on grounds of policy, other Courts have been less forgiving. ${ }^{260}$ The relevance of all this lies in the fact that South African social security is currently applying outdated laws too. As extensively analysed throughout this study, nowhere in the current social-insurance schemes or relevant social-assistance pension acts are posthumously-conceived children expressly or even at times, ${ }^{261}$ tacitly provided for. Furthermore, the evidence of the datedness in the South African current social-security survivors'benefits legislative framework is noticed by the schemes requirement of dependency to establish eligibility as well.

In the midst of all these negative similarities between the two social security legal systems, a silver lining exists. A paramount lesson that can be taken away is the balancing test, the yardstick, created by the Woodward $v$ Commissioner of Social Security Court. For the first time in the myriad cases dealing with a posthumously-conceived child claiming survivors' benefits, did a Court put in place an equitable standard that bore all affected parties' interests in mind. The relevance of this balancing test, equipped with its conditions for South Africa, is that currently as South Africa's social-security survivors'-benefits legal system stands, one could understandably perceive that the law is only bearing in mind, and unjustly protecting, the State's interests, to the exclusion of the child's interests and with disregard of the deceased's potential interest. Hence the value of this test is that it should be used as a barometer for South Africa's legislative reform. The Woodward balancing test should either be implemented and incorporated into the current social-security laws, or be utilized to draft an entirely new but feasible model for regulating posthumously-conceived children's specific rights and entitlements. Another impressive element in the decision raised in the matter was a suggestion that time limits might preclude qualifying for inheritance rights, even if the abovementioned conditions were satisfied.

Lastly, the assertion was made in several matters, based firstly on the fact that posthumously-conceived children are the natural biological children of the deceased and secondly because a marriage contract existed between their mother and her husband, that they are legitimate for the purposes of the Social Security Act. ${ }^{262}$ As a result of this assertion, the Capato II Court, when handing down judgment, raised important relevant facts by questioning whether the twins were indeed the children of married parents, stating that after all, Robert died before they were conceived, and a marriage is legally over when the first spouse dies. ${ }^{263}$ As such, they sought to dismiss such an assertion that children of married parents are automatically elevated in the

if the future will have as its polestar the best interest of the child". O' Brien $2009 \mathrm{~J}$. Contemp. Health L. \& Pol'y 385.

260 In both the Schafer $v$ Astrue supra 54-56 and Beeler v Astrue supra 936-965 matters, the Courts sought "to strictly interpret the statutes seeking to define a child as in existence at the death of a parent." O' Brien 2009 J. Contemp. Health L. \& Pol'y 385.

261 Namely the Special Pensions Act and Military Pensions Act. Furthermore, in COIDA posthumously-conceived children are not expressly provided for, but one may elect to infer that they may be/are tacitly provided for due to posthumous children being provided for under the Act.

262 Namely the Capato I and Gillett-Netting courts.

263 Grossman http://verdict.justia.com/2012/05/29/the-supreme-court-on-the-social-securityrights-of-posthumously-conceived-children 4. 
eyes of the law. The relevance of this particular issue is imperative to South Africa's private law pertaining to marriage, and consequently the legitimacy of posthumously-conceived children. This study is of the researched opinion that Capato I and Gillett-Netting Courts were on the right track, because the core purpose behind making such an assertion rested on the premise that, in establishing legitimacy, one could further establish and deem dependency on this class of children. Posthumously-conceived children being deemed dependent on the deceased is imperative in securing their entitlements to survivors' benefits because factual or legal dependency during the lifetime of the deceased is always a legal requirement. The key lesson for the South African legislature is in understanding that the Capato I/ verdict was solely based on the U.S. Supreme Court's unwillingness to interpret outside the ambit of the provisions of the Social Security Act. ${ }^{264}$ This unwillingness indicates to the judiciary's "cry out" for the legislature to intervene and amend the current survivors'-benefits regime. One might argue that it was right for the Supreme Court to leave the social-security question of parentage to the States, but the burden is now clearly on the States to clarify the rules.

Moving forward, the South African legislature should, when reforming the law, firstly consult with medical-law experts on how paternity should be ascertained for the purposes of posthumous conception and secondly, establish the particular requirements to be fulfilled when a posthumouslyconceived child needs to be legally deemed a dependant.

\section{CONCLUSION}

No uniform piece of social security legislation exists in South Africa regulating the different aspects of this branch of law. The problem is not per se, that the social-security survivors'-benefits legislative framework is scattered in various different schemes, but that the definition of what an eligible child is, varies from scheme to scheme. The problem lies in the inconsistency and the lack of a uniform definition of a dependant. Possible operable recommendations would either be for the legislature to remove the many different schemes and create one uniform codified piece of legislation that would adequately regulate every aspect of South Africa's social security law. ${ }^{265}$ This would be a viable option because it would guarantee that holistic concepts and definitions would be consistent throughout the social security spectrum. If overhauling the current legislative framework in favour of one uniform social security act seems to be too adventurous, then the second recommendation would be for policy-makers to ensure uniformity across the different schemes by providing a uniform definition for who an eligible child is, amongst others. Adequately answering the eligibility for benefits question will allow for the legislature to lay the foundation for a cohesive policy

264 The Court held that the Social Security Administration's interpretation, even if not the only reasonable one, was a permissible one of the Act.

265 A perfect example would be the United States Social Security Act. 
addressing the complex issues created by assisted reproduction and lifecycle manipulation. ${ }^{266}$

Another paramount reason for calling for the extensive reformation of the current social security survivors'-benefits laws pertaining to the timing of posthumously-conceived children's conception, is the negative implications that the private law rule of death dissolving a marriage when a spouse dies, has on this class of children. The fact that this category of children are born subsequent to a dissolution of a marriage questions their legitimacy, and consequently places their eligibility for survivor's benefits in further legal jeopardy. The unique, but entangled circumstances brought about by being conceived posthumously needs special consideration by policy-makers. It is for this precise reason that the third recommendation is that a separate but comprehensive category of survivors' benefits be created exclusively for this class of children. This recommendation is especially viable due to the fact that simply reading posthumously-conceived children's legal protection into the statutory provision won't work because all the social security survivors'benefits legislation never envisaged such a class of children and their unique characteristics when enacted. If anything, simply reading them and the necessary protection in could lead to even more inconsistencies and confusion. Going forward, equitable laws, specific to posthumouslyconceived children have to be put in place, in order to guarantee their adequate and satisfactory regulation.

The argument vying for the legislative reformation and update of the current survivors'-benefits framework is guided by and found in the Constitution. A brief analysis into the Constitution and its relevant sections has revealed that the Constitution envisages a country where every citizen, and indeed every child, will have protected fundamental rights which will be upheld by the State at all times. ${ }^{267}$ Furthermore the Constitution, as the supreme law of the Republic, accrues children child-specific rights in an effort to provide children with extra-special protection as vulnerable inherently dependent citizens of society, ${ }^{268}$ through its enactment of section 28. ${ }^{269}$ And lastly, with the introduction of the new constitutional dispensation, every citizen and their dependants was provided with the right of access to social security. As such the constitutional obligation placed on the State implies that legislation, amongst others relating to children, should always be in line with what was envisaged, which essentially was to put the "best interest" standard as paramount in every matter pertaining to the child.

It is further recommended that the balancing testing created by the Woodward $v$ Commissioner of Social Security case ultimately serves as a guiding principle for what a feasible South African model, adequately regulating and considering what all affected interests, should contain and look like. This recommended, feasible model could be used to either amend

266 Droghazi 200583 Washington University Law Quarterly (WASHULQ) 1620. For eg, human cloning and genetically engineered children.

267 Any law or conduct that is not in accordance with the Constitution, either for procedural or substantive reasons, will therefore not have the force of law.

268 In terms of $s$ 28(2), a child's interests are of paramount importance in every matter concerning that child

269 Ibid. 
posthumously-conceived children's entitlements to social security survivors' benefits, or alternatively, to promulgate a separate piece of legislation, clarifying and setting out the conditions to be fulfilled by posthumouslyconceived children in order to establish their eligibility for social security survivors' benefits. If these proposed requirements are not satisfied, then such a child could be deemed ineligible. 